\title{
Dynamic Metasomatism: Stable Isotopes, Fluid Evolution, and Deformation of Albitite and Scapolite Metagabbro (Bamble Lithotectonic Domain, South Norway)
}

\author{
Ane K. Engvik $\mathbb{D}^{1},{ }^{1}$ Heinrich Taubald, ${ }^{2}$ Arne Solli, ${ }^{1}$ Tor Grenne, ${ }^{1}$ and Håkon Austrheim ${ }^{3}$ \\ ${ }^{1}$ Geological Survey of Norway, P.O. Box 6315 Torgard, 7491 Trondheim, Norway \\ ${ }^{2}$ Department of Geosciences, University of Tübingen, Wilhelmstr. 56, 72074 Tübingen, Germany \\ ${ }^{3}$ Department of Geosciences, University of Oslo, P.O. Box 1047 Blindern, 0316 Oslo, Norway \\ Correspondence should be addressed to Ane K. Engvik; ane.engvik@ngu.no
}

Received 22 June 2017; Revised 21 October 2017; Accepted 4 December 2017; Published 17 January 2018

Academic Editor: Daniel E. Harlov

Copyright (C) 2018 Ane K. Engvik et al. This is an open access article distributed under the Creative Commons Attribution License, which permits unrestricted use, distribution, and reproduction in any medium, provided the original work is properly cited.

\begin{abstract}
New stable isotopic data from mineral separates of albite, scapolite, amphibole, quartz, and calcite of metasomatic rocks (Bamble lithotectonic domain) give increased knowledge on fluid type, source, and evolution during metamorphism. Albite from a variety of albitites gives $\delta^{18} \mathrm{O}_{\text {SMOW }}$ values of 5.1-11.1\%, while quartz from clinopyroxene-bearing albitite gives $11.5-11.6 \%$. $\delta^{18} \mathrm{O}_{\text {SMOW }}$ values for calcite samples varies between 3.4 and $12.4 \%$ and shows more consistent $\delta^{13} \mathrm{C}$ values of -4.6 to $-6.0 \%$. Amphibole from scapolite metagabbro yields a $\delta^{18} \mathrm{O}_{\mathrm{SMOW}}$ value of 4.3 to $6.7 \%$ and $\delta \mathrm{D}_{\text {SMOW }}$ value of -84 to $-50 \%$, while the scapolite gives $\delta^{18} \mathrm{O}_{\mathrm{SMOW}}$ values in the range of 7.4 to $10.6 \%$. These results support the interpretation that the original magmatic rocks were metasomatised by seawater solutions with a possible involvement from magmatic fluids. Scapolitisation and albitisation led to contrasting chemical evolution with respect to elements like $\mathrm{P}, \mathrm{Ti}, \mathrm{V}, \mathrm{Fe}$, and halogens. The halogens deposited as $\mathrm{Cl}$-scapolite were dissolved by albitisation fluid and reused as a ligand for metal transport. Many of the metal deposits in the Bamble lithotectonic domain, including Fe-ores, rutile, and apatite deposits formed during metasomatism. Brittle to ductile deformation concurrent with metasomatic infiltration illustrates the dynamics and importance of metasomatic processes during crustal evolution.
\end{abstract}

\section{Introduction}

Metasomatism is the pervasive alteration of rocks with respect to both mineralogical and chemical composition. It results from interaction with fluids, sometimes causing albitisation by replacement of rock units by Na-rich feldspar, and scapolitisation forming scapolite-bearing rocks. These fluids can infiltrate under highly variable geological settings and PT conditions and originate from a meteoric, magmatic, or metamorphic environment. Albitisation is reported in deep weathering profiles $[1,2]$, in epiclastic sediments during diagenesis and low-grade metamorphism [3], in granitoids during late magmatic alteration [4], and in association with fluid migration in mobile belts [5]. Regional-scale metasomatism is a widely recognized phenomenon in a number of rock types and tectonic settings [6,7]. Metasomatism is an important guide to hydrothermal ore deposits and represents a characteristic feature of many orogenic gold deposits, iron oxide-apatite (IOA), iron oxide-Cu-Au (IOCG), and U deposits [6, 8-11].

The Bamble and Kongsberg-Modum lithotectonic domains of south Norway represent classic high-grade metamorphic terrains [12-18], which contain a series of different metasomatic rocks. An early scapolitisation event, where Clrich scapolite coexisted with enstatite, phlogopite, amphibole, and rutile is constrained at 600 to $700^{\circ} \mathrm{C}$ at mid-crustal levels [19-21]. Mg-Al-rich lithologies such as orthoamphibolecordierite schists occur together with scapolitised rocks [22]. Subsequently, albitisation transformed scapolite metagabbro and regionally distributed mafic and granitoid rocks to albitites, dominated by albite, with varying amounts of rutile, carbonate, chlorite, and locally prehnite, pumpellyite, and analcime. Albitisation is widespread in the Mesoproterozoic rocks of the Sveconorwegian orogen in southern Scandinavia (Figure 1) $[18,21,23]$. In addition, the Bamble and KongsbergModum lithotectonic domains are characterised by a high 


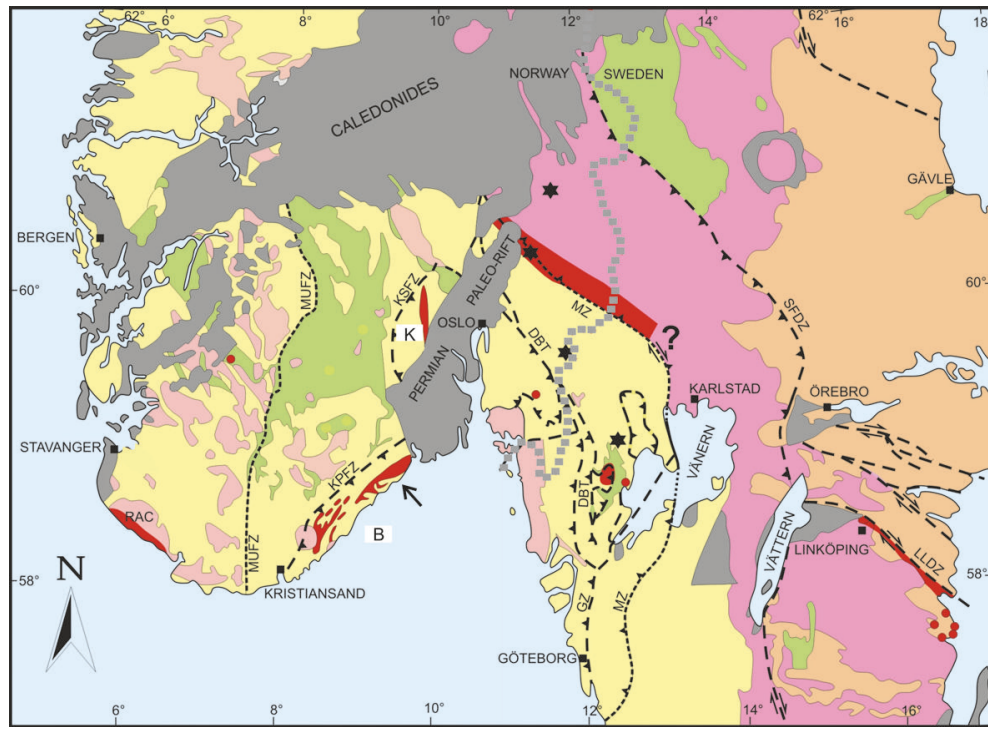

Neoproterozoicpalaeozoic formations $(<0.8 \mathrm{Ga})$ Late to post-Sveconorwegian intrusions $(0.92-1.0 \mathrm{Ga})$ Low- to medium-grade Mesoproterozoic supracrustals (1.53-1.05 Ga)

Medium- to high-grade gneiss complexes (1.73-1.25 Ga)

TIB-type granitoids and orthogneisses $(1.88-1.65 \mathrm{Ga})$

Svecofennian rocks $(>1.89 \mathrm{Ga})$
Areas with widespread Na-metasomatism

- Local occurrences of Na-metasomatic rocks

* Chlorite-cemented breccia pipes with associated albitisation

- - Major low- and high-angle shear zones with dip indicated

$(\mathrm{km})$

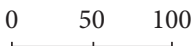

(a)

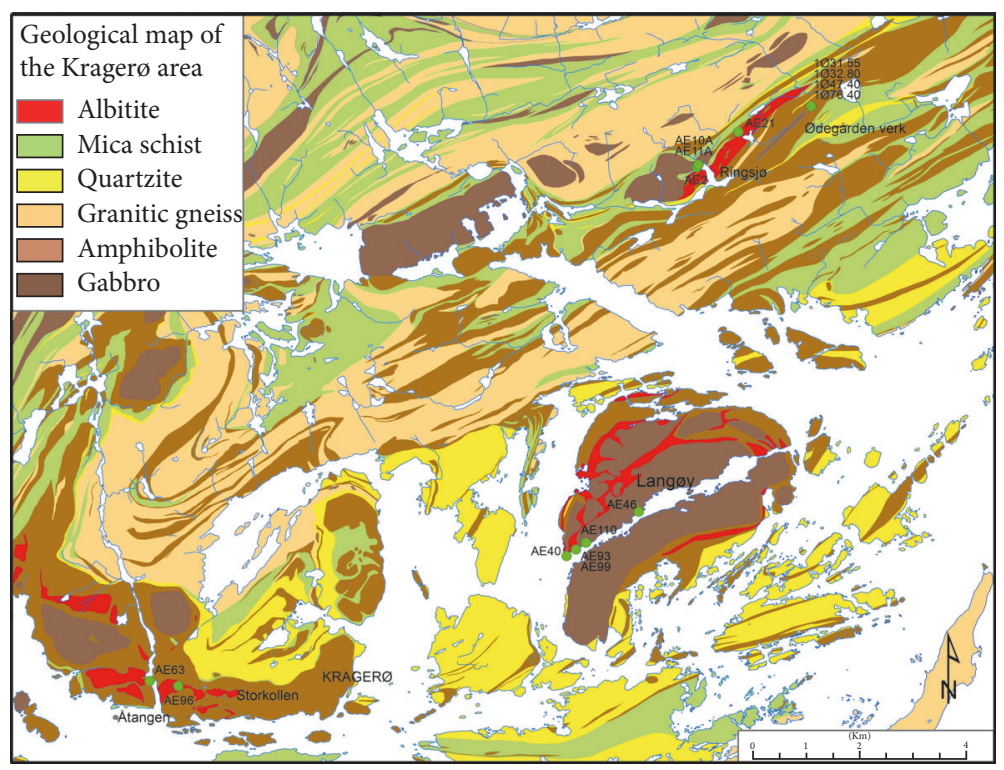

(b)

Figure 1: (a) Regional geological map of south Norway and Sweden indicating areas of widespread Na-metasomatism [23]. Arrow indicating the study area (Figure $1(\mathrm{~b})$ ). $\mathrm{B}=$ Bamble lithotectonic domain; $\mathrm{K}=$ Kongsberg-Modum lithotectonic domain; RAC $=\mathrm{Rogaland}$ Anorthosite Complex; KPFZ = Kristiansand-Porsgrunn Fault Zone; KSFZ = Kongsberg-Sokna Fault Zone; MZ = Mylonite Zone; DBT = Dalsland Boundary Thrust; GZ = Götaelv Zone; SFCZ = Sveconorwegian Frontal Deformation Zone; and LLDZ = Linköping-Lofthammer Deformation Zone. (b) Geological map of the investigated Kragerø area in the Bamble lithotectonic domain with sample localities. 
density of mineral deposits including the common occurrence of apatite and rutile deposits $[23,24]$ and a high density of hydrothermal Fe-deposits including veins and breccias of nickeliferous pyrrhotite-apatite, magnetite-apatite, magnetite and hematite, and Fe-oxide skarn deposits $[25,26]$.

The metasomatic processes affecting the Bamble lithotectonic domain have locally transformed the rocks so strongly that we cannot trace the precursor, and therefore a full understanding of the processes is still lacking. However, a number of papers have solved various aspects of the metasomatic processes including widespread formation of scapolite metagabbro [19-21, 27] through $\mathrm{Mg}-\mathrm{Cl}$ metasomatism, replacement textures in apatite [28-30], rutile formation [31], carbonate deposition [32], tourmaline formation [33], and sapphirine-corundum crystallization [34]. While the scapolitisation process with respect to mineral reactions is relatively well understood in the Kragerø region, albitisation is a more complex process and less constrained. Extensive albitisation is seen along veins, as brecciation, as formation of foliated albititic felsites and chlorite schists, as carbonate-rich albitite, and as large-scale albitite bodies $[23,35]$.

In this paper, we present stable $\mathrm{O}-, \mathrm{H}$-, and $\mathrm{C}$-isotope data on mineral separates from albitites and scapolite metagabbro with the purpose of constraining the fluid type and source. Different models for fluid evolution are then discussed. Whole rock geochemical data is presented in order to illustrate the chemical changes and discussed relative to mineralogical replacement and mineral deposition. Brittle and ductile structural elements associated with the metasomatism are used to discuss the dynamics of fluid processes.

\section{Geological Setting}

The Sveconorwegian orogenic belt in SW Scandinavia consists of late Palaeoproterozoic to Mesoproterozoic continental crust reworked during the Sveconorwegian orogeny [18, 41, 42]. The orogen is divided into several lithotectonic gneiss domains separated by crustal scale shear zones (Figure 1(a)). The Bamble lithotectonic domain in south Norway shows a SW-NE structural trend and consists of high-grade orthoand paragneisses and amphibolites [43]. The oldest known rocks are orthogneisses ranging in age from ca. 1570 to $1460 \mathrm{Ma}$ [44-46]. They are intruded by younger plutonic rocks, including a $1294 \pm 38 \mathrm{Ma}$ tonalite pluton [20], 1200 to $1150 \mathrm{Ma}$ mafic and felsic plutonic rocks [20, 45, 46], ca. $1060 \mathrm{Ma}$ pegmatite bodies [47], and ca. 990 to $925 \mathrm{Ma}$ Sveconorwegian postcollisional granite plutons [45]. The studied area is located close to the Oslo Rift with abundant magmatic activity in Permian time (Figure 1(a)).

Metamorphism in Bamble was associated with regionalscale deformation and the formation of a strong lithological and regional NE-SW tectonic banding. Zircon, monazite, titanite, and rutile $\mathrm{U}-\mathrm{Pb}$ ages from the area place the highgrade metamorphism as part of an early phase of the Sveconorwegian orogeny in the time interval 1140-1080 Ma [20, 41, 48-50]. The gneisses are dominantly amphibolite-facies, with metamorphic grade increasing to granulite-facies in the Arendal area $\left(P=0.6-0.8 \mathrm{GPa} ; T=750-850^{\circ} \mathrm{C}\right)[13,16,51$, 52]. In addition, there are several occurrences of rocks with granulite-facies assemblages, including charnockitic gneiss bodies, as well as conformable lenses and layers of sapphirinebearing rocks $[14,53]$, which are exposed north of Arendal and Kragerø [17, 54, 55].

The Kragerø area (Figure 1(b)) consists of a layered complex of mafic rocks and variable gneisses and quartzites. The mafic rocks are amphibolites and metagabbros including bodies of gabbro [56]. Orthogneisses are of granitic, granodioritic, quartzdioritic, and tonalitic composition. Quartzites containing sillimanite are interlayered with garnet amphibolite, felsic gneiss, and garnet- and cordierite-bearing mica gneiss.

Na-metasomatism in the form of albitisation is regionally extensive in the Precambrian crust of southern Scandinavia and is particularly widespread in the Bamble and KongsbergModum lithotectonic domains and the Norwegian part of the Mylonite Zone (Figure 1(a)) [23]. In the Bamble lithotectonic domain, albitisation is present from the northeastern boundary to the Oslo Rift and southwestwards through the domain. Large bodies of albitite are found in the vicinity of Kragerø and towards Arendal [23, 57-59]. Mg-Cl-metasomatised rocks in the form of scapolite metagabbros occur widespread as part of the mapped amphibolites and metagabbro, commonly in conjunction with the albitites $[19,20,50]$.

\section{Analytical Methods}

Different types of albitites and scapolite metagabbro were mapped and sampled in the Kragerø area of Bamble lithotectonic domain (Table 1; Figure 1). Polished thin sections were studied via optical and scanning electron microscopy (SEM), using a LEO 1450 VP instrument at the Geological Survey of Norway (NGU).

Whole rock major and trace element analyses (Table 2) were carried out at the NGU. Major elements were measured on fused glass beads prepared by $1: 7$ dilution with lithium tetraborate. Trace elements were measured from pressed tablets. The samples were analysed on a PANalytical Axios XRF spectrometre equipped with a $4 \mathrm{~kW}$ Rh X-ray endwindow tube, using synthetic and international standards for calibration as described by Govindaraju [60]. Rock samples used for whole rock geochemistry were selected as being representative and homogenous, with good control on mineralogy and petrography.

Stable isotopic data are presented in Table 3 . The oxygen isotope composition $\left({ }^{16} \mathrm{O},{ }^{17} \mathrm{O}\right.$, and $\left.{ }^{18} \mathrm{O}\right)$ of handpicked mineral separates of albite, scapolite, amphibole, and quartz was measured at the University of Tübingen using a method similar to that described by Sharp [61] and Rumble III and Hoering [62], which is described in more detail in Kasemann et al. [63]. Between 2 to $4 \mathrm{mg}$ of sample was loaded onto a small Pt sample holder, which was pumped to a vacuum of about $10^{-6}$ mbar. After prefluorination of the sample chamber overnight, the samples were heated with a $\mathrm{CO}_{2}$-laser in 50 mbars of pure $\mathrm{F}_{2}$. Excess $\mathrm{F}_{2}$ was separated from the $\mathrm{O}_{2}$ using $\mathrm{KCl}$ at $150^{\circ} \mathrm{C}$ by producing $\mathrm{KF}$ and releasing $\mathrm{Cl}_{2}$. The extracted $\mathrm{O}_{2}$ was collected quantitatively by adsorption on a molecular sieve (13X) at liquid nitrogen temperature in a sample vial. Subsequently the vial was removed from the 


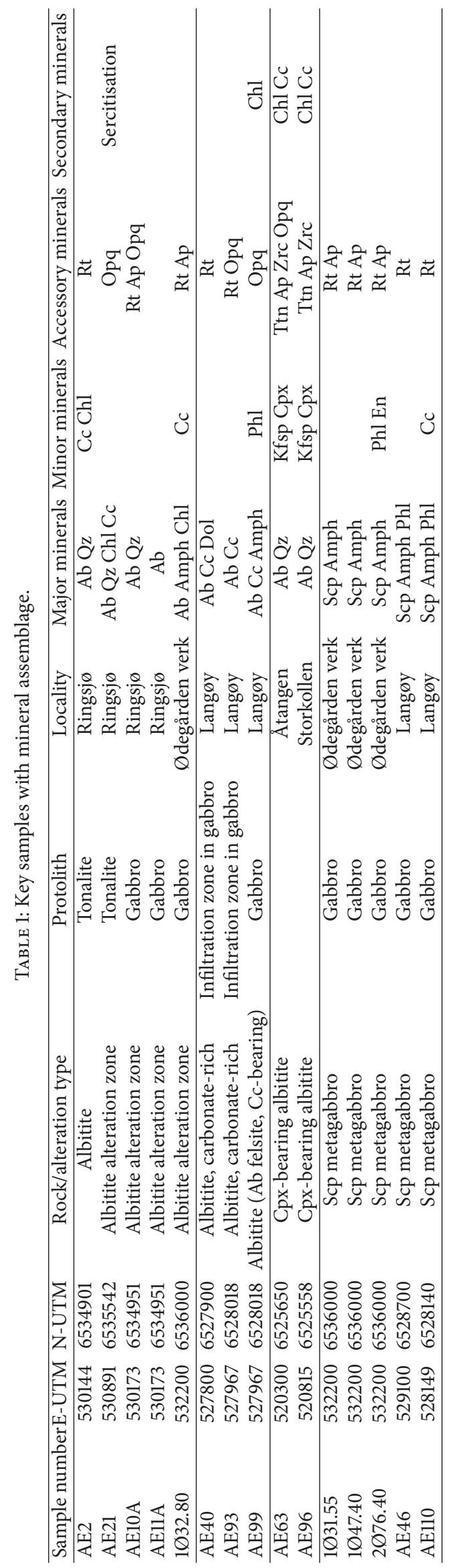




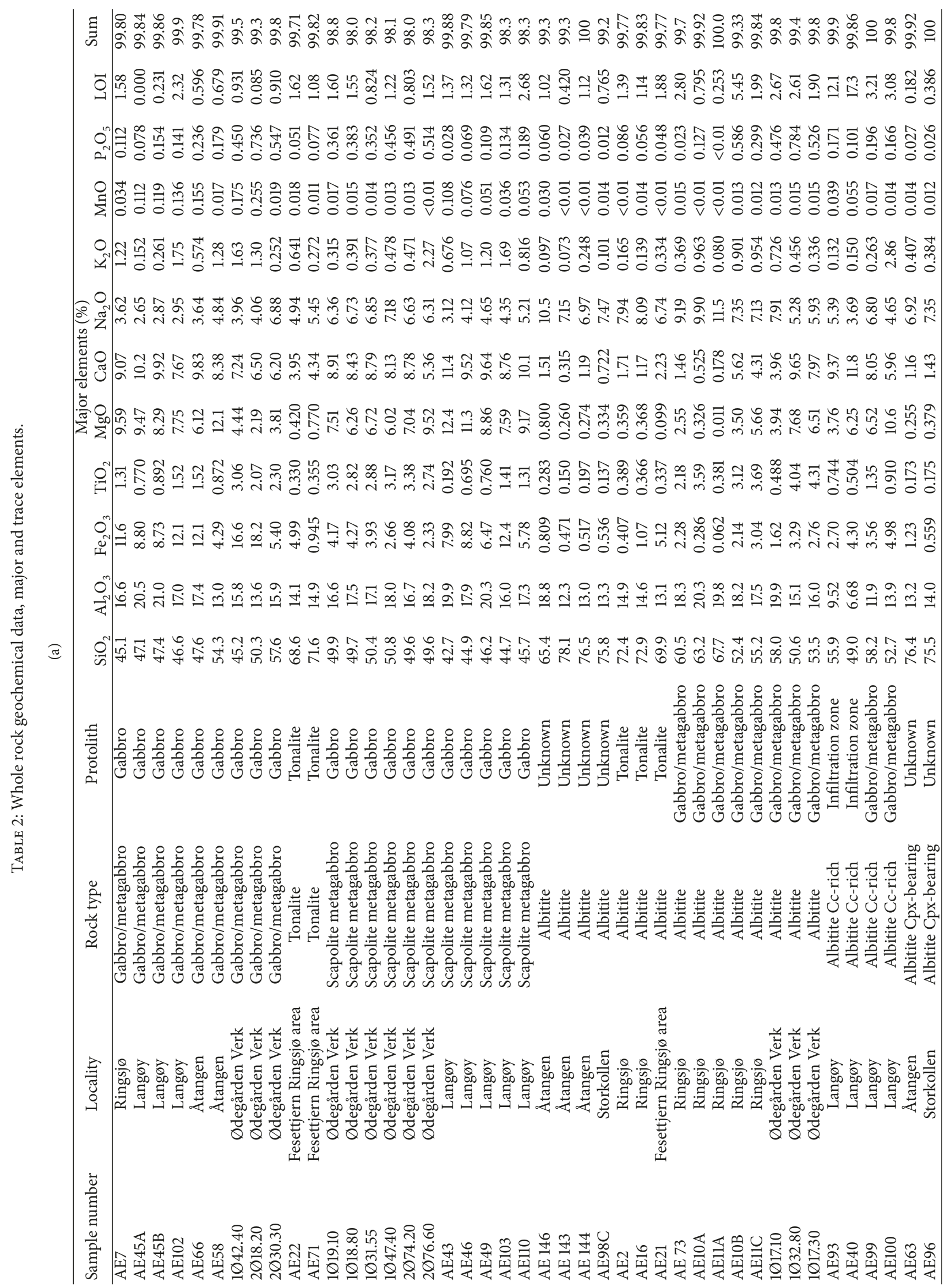




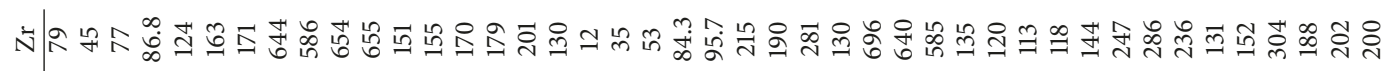

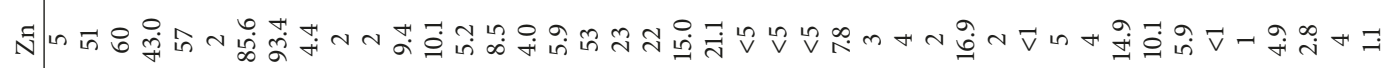

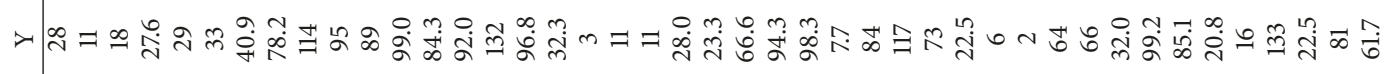
$>$ œ ळ

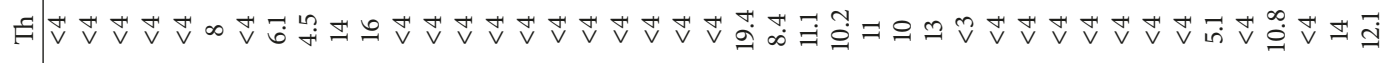

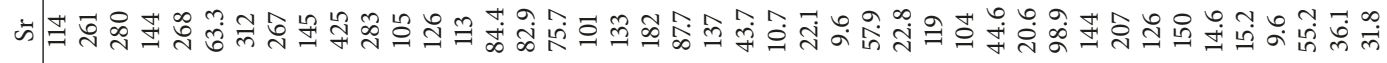

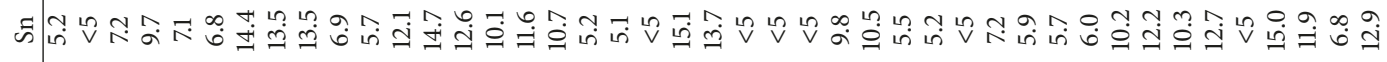

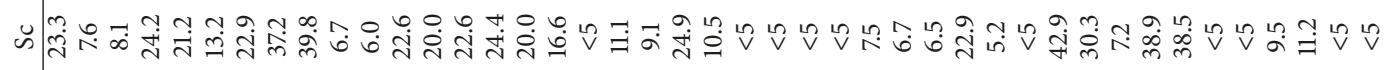

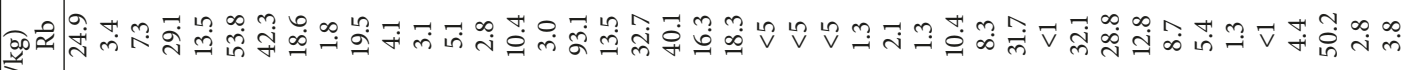

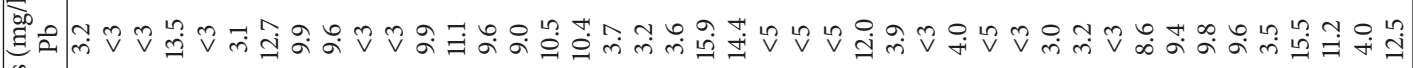

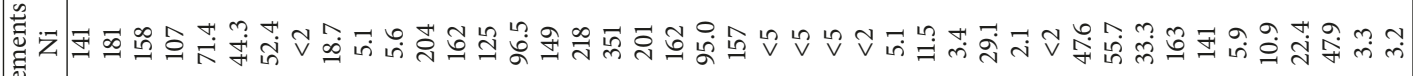
鸟

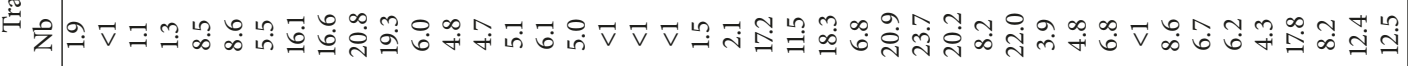

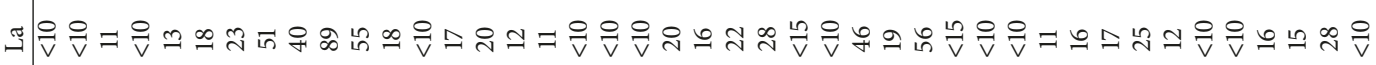
Ð

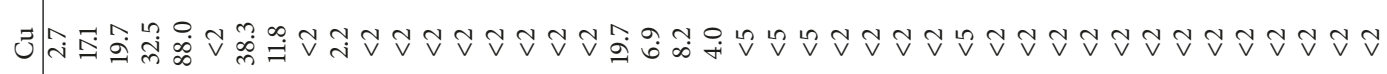

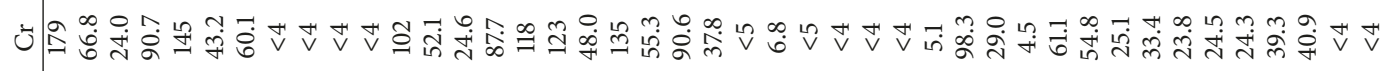

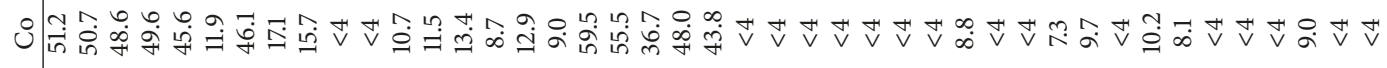

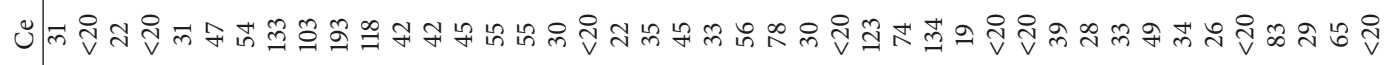

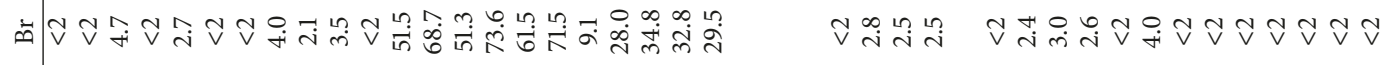

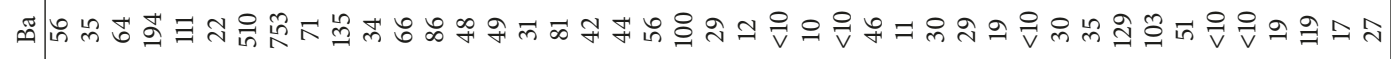

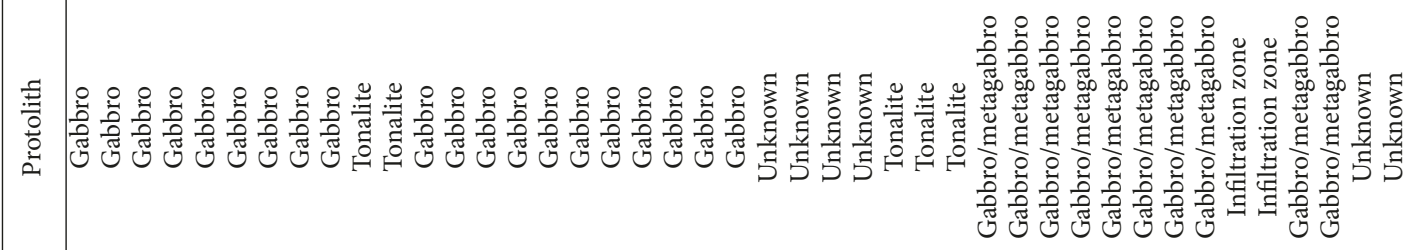

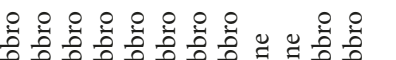

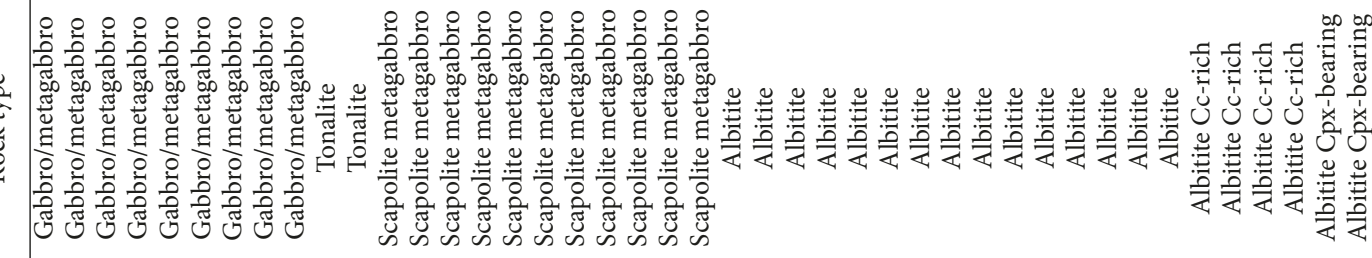

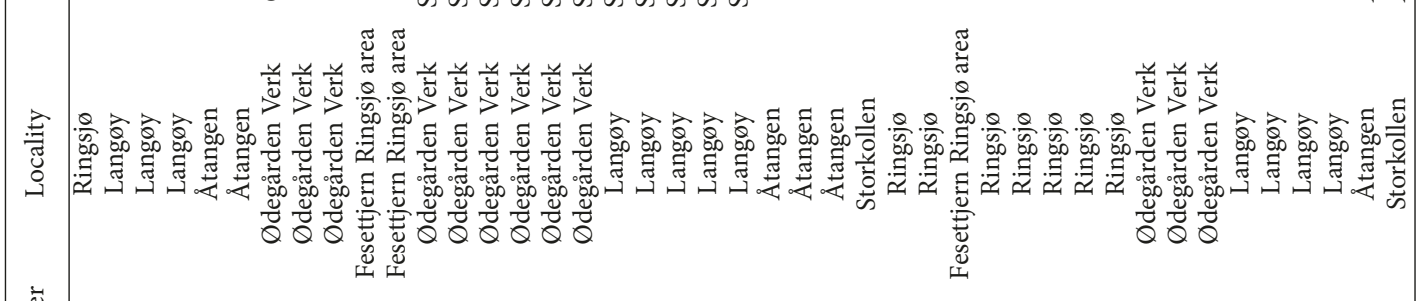


TABLe 3: Stable isotopic data.

\begin{tabular}{|c|c|c|c|c|c|c|c|c|}
\hline $\begin{array}{l}\text { Sample } \\
\text { number }\end{array}$ & Mineral & Rock type & Protolith & Locality & $\begin{array}{c}\delta^{18} \mathrm{O}_{\text {SMOW }} \\
(\%)\end{array}$ & $\delta \mathrm{D}_{\text {SMOW }}(\% \mathrm{o})$ & $\delta^{13} \mathrm{C}_{\mathrm{PDB}}(\%)$ & $\begin{array}{c}\mathrm{CO}_{3} \\
\left(\% \mathrm{CaCO}_{3}\right) \\
\end{array}$ \\
\hline AE 2 & Albite & Albitite & Tonalite & Ringsjø & 8.5 & & & \\
\hline $\mathrm{AE} 21$ & Albite & $\begin{array}{l}\text { Albitite } \\
\text { alteration zone }\end{array}$ & Tonalite & Ringsjø & 10.8 & & & \\
\hline $\mathrm{AE} 10 \mathrm{~A}$ & Albite & $\begin{array}{l}\text { Albitite } \\
\text { alteration zone }\end{array}$ & Gabbro & Ringsjø & 5.1 & & & \\
\hline AE 11A & Albite & $\begin{array}{l}\text { Albitite } \\
\text { alteration zone }\end{array}$ & Gabbro & Ringsjø & 7.7 & & & \\
\hline $1 \varnothing 32.80$ & Albite & $\begin{array}{c}\text { Albitite } \\
\text { alteration zone }\end{array}$ & Gabbro & $\begin{array}{l}\text { Ødegården } \\
\text { Verk }\end{array}$ & 8.4 & & & \\
\hline $\mathrm{AE} 40$ & Albite & $\begin{array}{l}\text { Albitite, } \\
\text { carbonate-rich }\end{array}$ & $\begin{array}{l}\text { Infiltration in } \\
\text { gabbro }\end{array}$ & Langøy & 7.0 & & & \\
\hline AE 93 & Albite & $\begin{array}{l}\text { Albitite, } \\
\text { carbonate-rich }\end{array}$ & $\begin{array}{l}\text { Infiltration in } \\
\text { gabbro }\end{array}$ & Langøy & 6.3 & & & \\
\hline AE 99 & Albite & $\begin{array}{c}\text { Albitite }(\mathrm{Ab} \\
\text { felsite, Cc-rich) }\end{array}$ & Gabbro & Langøy & 5.5 & & & \\
\hline $\mathrm{AE} 63$ & Albite & $\begin{array}{l}\text { Cpx-bearing } \\
\text { albitite }\end{array}$ & (Unknown) & Åtangen & 10.8 & & & \\
\hline AE 96 & Albite & $\begin{array}{l}\text { Cpx-bearing } \\
\text { albitite }\end{array}$ & (Unknown) & Storkollen & 11.1 & & & \\
\hline $\mathrm{AE} 63$ & Quartz & $\begin{array}{l}\text { Cpx-bearing } \\
\text { albitite }\end{array}$ & (Unknown) & Åtangen & 11.6 & & & \\
\hline AE 96 & Quartz & $\begin{array}{l}\text { Cpx-bearing } \\
\text { albitite }\end{array}$ & (Unknown) & Storkollen & 11.5 & & & \\
\hline AE 2 & Calcite & Albitite & Tonalite & Ringsjø & 4.5 & & -5.7 & 1.6 \\
\hline $\mathrm{AE} 21$ & Calcite & $\begin{array}{l}\text { Albitite } \\
\text { alteration zone }\end{array}$ & Tonalite & Ringsjø & 10.5 & & -6.0 & 6.1 \\
\hline $\mathrm{AE} 40$ & Calcite & $\begin{array}{l}\text { Albitite, } \\
\text { carbonate-rich }\end{array}$ & $\begin{array}{l}\text { Infiltration in } \\
\text { gabbro }\end{array}$ & Langøy & 5.8 & & -5.0 & 1.0 \\
\hline AE 93 & Calcite & $\begin{array}{l}\text { Albitite, } \\
\text { carbonate-rich }\end{array}$ & $\begin{array}{l}\text { Infiltration in } \\
\text { gabbro }\end{array}$ & Langøy & 12.4 & & -5.6 & 2.0 \\
\hline AE 99 & Calcite & $\begin{array}{c}\text { Albitite (Ab } \\
\text { felsite, Cc-rich) }\end{array}$ & Gabbro & Langøy & 3.4 & & -4.6 & 28.1 \\
\hline $1 \varnothing 31.55$ & Scapolite & Scp metagabbro & Gabbro & $\begin{array}{l}\text { Ødegården } \\
\text { Verk }\end{array}$ & 9.1 & & & \\
\hline $1 \varnothing 47.40$ & Scapolite & Scp metagabbro & Gabbro & $\begin{array}{l}\text { Ødegården } \\
\text { Verk }\end{array}$ & 8.4 & & & \\
\hline 2076.40 & Scapolite & Scp metagabbro & Gabbro & $\begin{array}{l}\text { Ødegården } \\
\text { Verk }\end{array}$ & 10.6 & & & \\
\hline $\mathrm{AE} 46$ & Scapolite & Scp metagabbro & Gabbro & Langøy & 8.2 & & & \\
\hline $\mathrm{AE} 110$ & Scapolite & Scp metagabbro & Gabbro & Langøy & 7.4 & & & \\
\hline $1 \varnothing 31.55$ & Amphibole & Scp metagabbro & Gabbro & $\begin{array}{l}\text { Ødegården } \\
\text { Verk }\end{array}$ & 4.3 & -51 & & \\
\hline $1 \varnothing 47.40$ & Amphibole & Scp metagabbro & Gabbro & $\begin{array}{l}\text { Ødegården } \\
\text { Verk }\end{array}$ & 6.2 & -51 & & \\
\hline $2 \varnothing 76.40$ & Amphibole & Scp metagabbro & Gabbro & $\begin{array}{l}\text { Ødegården } \\
\text { Verk }\end{array}$ & 6.7 & -59 & & \\
\hline AE 46 & Amphibole & Scp metagabbro & Gabbro & Langøy & 4.3 & -57 & & \\
\hline $\mathrm{AE} 110$ & Amphibole & Scp metagabbro & Gabbro & Langøy & 5.6 & -84 & & \\
\hline
\end{tabular}

Overall analytical precision for $\mathrm{O}: \pm 0.2$; overall analytical precision for $\mathrm{H}: \pm 2.0$; overall analytical precision for $\mathrm{C}: \pm 0.1$. 
line and heated to room temperature; thus, $\mathrm{O}_{2}$ is released as a gas and eventually analysed isotopically using a Finnigan MAT 252 isotope ratio mass spectrometer. Oxygen isotope compositions are given in the standard $\delta$-notation and expressed relative to SMOW (Vienna Standard Mean Ocean Water) in permil (\%o). Replicate oxygen isotope analyses of the standards, using NBS-28 quartz and UWG-2 garnet [64], generally have an average precision of $\pm 0.1 \%$ for $\delta^{18} \mathrm{O}$. The accuracy of $\delta^{18} \mathrm{O}$ values is commonly better than $0.2 \%$ compared to the accepted $\delta^{18} \mathrm{O}$ values for NBS-28 of $9.64 \%$ o and UWG- 2 of $5.8 \%$.

For the $\mathrm{D} / \mathrm{H}$ analysis of the minerals, an extraction line as described in [65] was used. Depending on the water content, a sufficient amount of hydrous minerals was loaded into $12 \mathrm{~cm}$ long quartz tubes in order to obtain $>1 \mathrm{mg} \mathrm{H}_{2} \mathrm{O}$. Water was released by heating the minerals in the tubes using a torch. $\mathrm{H}_{2} \mathrm{O}$ was then converted to $\mathrm{H}_{2}$ using $\mathrm{Zn}$ (see also Vennemann and $\mathrm{O}^{\prime} \mathrm{Neil}$ [65] for further details). $\mathrm{H}_{2}$ was then subsequently measured by a Finnigan MAT 252 Mass Spectrometer, using the dual inlet device. External precision is typically $\pm 2 \%$, and all values are reported relative to SMOW.

Stable isotope analysis (C, O) of carbonate samples was performed using a Finnigan MAT 252 gas source mass spectrometer combined with a Thermo Finnigan GasBench II/CTC Combi-Pal autosampler. Both devices are connected using the continuous flow technique with a $\mathrm{He}$ stream as carrier gas. About $0.1 \mathrm{mg}$ dried sample powder is loaded into a $10 \mathrm{ml}$ glass exetainer, sealed with rubber septum. The exetainers are placed in an aluminium tray and set to $72^{\circ} \mathrm{C}$. After purging with pure He gas, 4-6 drops of $100 \%$ phosphoric acid are added. After a reaction time of about 90 minutes, the released $\mathrm{CO}_{2}$ is transferred (using a GC gas column to separate other components) to the mass spectrometer using a $\mathrm{He}$ carrier gas. The sample $\mathrm{CO}_{2}$ is measured relative to an internal laboratory tank gas standard, which is calibrated against internal and international carbonate standards (e.g., Laser marble, NBS-19). All values are given in \%o relative to PDB (Vienna Pee Dee Belemnite) for C and $\mathrm{SMOW} / \mathrm{PDB}$ for $\mathrm{O}$. The external precision calculated over $10-15$ standards is typically in the range of $0.05-0.06 \%$ o for $\delta^{13} \mathrm{C}$ and $0.06-0.08 \%$ or for $\delta^{18} \mathrm{O}$. For further details see Spötl and Vennemann [66].

\section{Na- and Mg-Cl-Metasomatic Rocks}

4.1. Field and Structural Relations. In the Kragerø area, MgCl-metasomatised scapolite-bearing rocks occur widespread as a part of the mapped amphibolite, metagabbro, and gabbro lithologies $[19,20,23]$ and have been studied in detail at Ødegården Verk, Ringsjø, Åtangen, Valberg, and Langøy localities (Figure 1(b)). At Langøy and Ødegården Verk, transformation of pristine gabbro to scapolite metagabbro is observed along fluid fronts (Figure 2(a)). Medium-grained dark gabbro including olivine and pyroxenes is transformed into a medium- to coarse-grained scapolite metagabbro. The scapolite metagabbro occurs as an equigranular massive rock originally named ødegårdite [57]. Frequently, the scapolite metagabbro displays veining in the form of $0.5-2 \mathrm{~cm}$ wide veins, which are composed of the major rock-forming minerals scapolite, amphibole (edenite, pargasite, and actinolite), or phlogopite (Figures 2(b)-2(d)). Locally, this veining occurs with a high density initiating a layered structure in the rock (Figure 2(c)). The veining and banded structure develops during progressive deformation and formation of the rock foliation (Figure 2(d)). At the Åtangen locality, dynamic scapolitisation through synchronous brecciation is observed, where amphibolite and banded host schist are found as inclusions in a matrix of scapolite (Figures $2(\mathrm{e})-2(\mathrm{~g}))$. White scapolite forms veins, or a scapolite-amphibole assemblage forms the groundmass in evolved breccias with rounded clasts. The veined and brecciated structure undergoes flattening (Figure $2(\mathrm{~g})$ ), evolving to a foliated scapolite-bearing amphibolitic rock (Figure 2(h)).

Albitisation affects both mafic and granitoid lithologies in the Kragerø area, usually associated with the scapolitebearing rocks, and normally postdating the scapolitisation. Albitisation takes place along veins and in breccias. Albite is the dominant mineral in foliated felsites, in chlorite schist, in carbonate-rich albitite, and in large-scale albitite bodies $[23,50]$. Albitisation has been studied in detail in the RingsjøØdegården Verk area [20, 35]. Both mafic (gabbro, scapolite metagabbro, and amphibolite) and granitoid protolith are transformed to albitite along veining, where the central vein consists of nearly pure albite (Figures 3(a)-3(b)). The replacement zone to the mafic host rock shows a widespread replacement of the mafic phases to chlorite (Figure 3(c)). Intensive albitisation affects part of the area resulting in a $0.5 \times 2 \mathrm{~km}$ albitite body (Figure 1(b))

At the Langøy locality, albitite extends over a $3 \times 2 \mathrm{~km}$ area and follows a mapped vein-pattern through gabbro, metagabbro, and scapolite metagabbro rocks (Figure 1(b)). It includes massive carbonate-rich albitite, brecciated and altered host rock with albite-carbonate groundmass, and foliated albitic felsites. The massive carbonate-rich albitite usually occurs as several-meter thick deposits (Figure 3(d)) with the largest albitite body being more than $150 \mathrm{~m}$ wide and $1500 \mathrm{~m}$ long (Figure 1(b)). They are brecciated along their margins (Figure 3(e)) to the scapolite metagabbro with a gradational contact. The initial transformation and disintegration of the metagabbro protolith are observed along and adjacent to the individual albititic veins (Figure 3(f)). Progressive deformation and infiltration caused brecciation, with an albititic groundmass infiltrating angular clasts of greenishgrey, retrograded mafic rock, and progressively developing a foliation fabric. These foliated albite-rich felsites are rocks with layers of light carbonate-albite dominated bands layered with green-grey chlorite schist, after veined, brecciated, and flattened metagabbro (Figure 3(g)).

In the Storkollen-Åtangen area, west of the town of Kragerø, large-scale albititic bodies covering $>1 \mathrm{~km}^{2}$ are enveloped by amphibolites, metagabbro, and scapolite metagabbro. The albitite is clinopyroxene- and titanite-bearing. It characteristically takes the form of a medium-grained, granoblastic, light grey, or pink leucocratic rock (Figure 3(h)). It is either massive or has a gneissic banding formed by alternating leucocratic and amphibole-bearing melanocratic layers. 


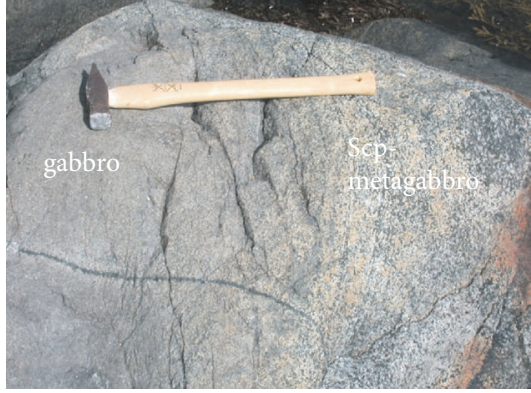

(a)

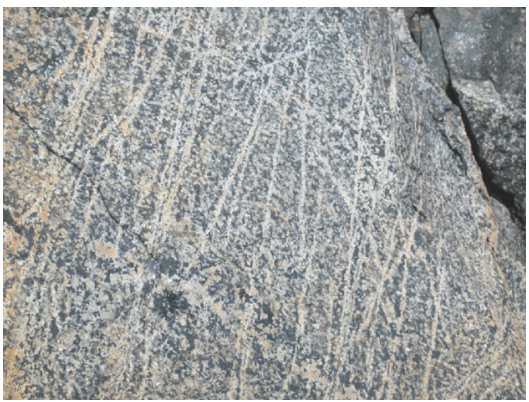

(c)

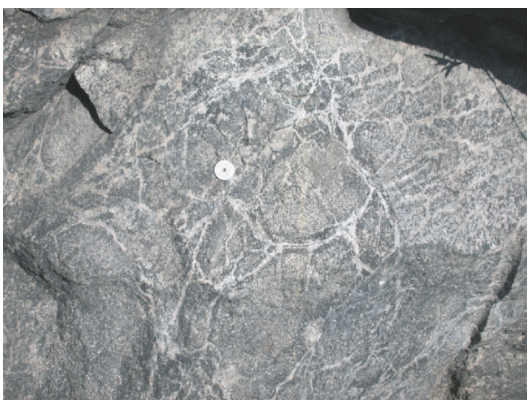

(e)

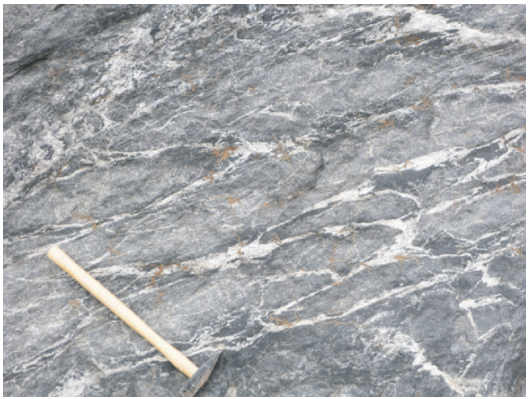

(g)

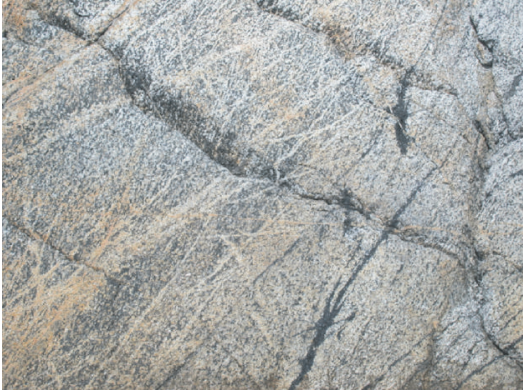

(b)

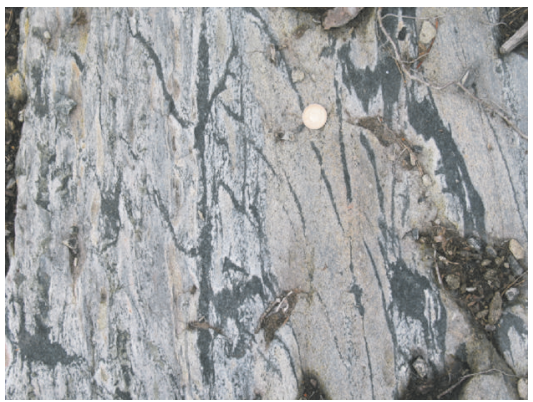

(d)

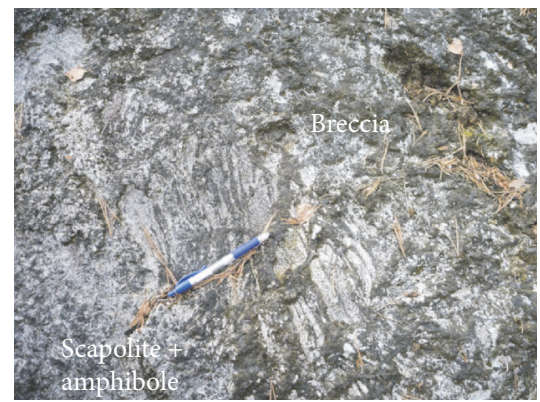

(f)

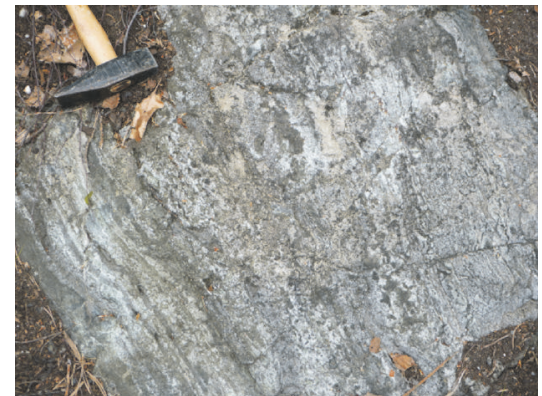

(h)

FIGURE 2: Field photos of scapolite metagabbro and dynamic scapolitisation. (a) Gabbro with scapolitisation front. Locality Langøy. (b) Scapolite metagabbro with veining filled by scapolite and amphibole. Field of view is approximately one metre wide. Locality Langøy. (c) Scapolite metagabbro with a high density of scapolite veining resulting in a layered structure in the rock [20]. Field of view is approximately one metre wide. Locality Langøy. (d) Scapolite metagabbro with amphibole veining and flattened foliation [20]. Locality Langøy. (e) Brecciated amphibolite with a thin scapolite vein filling and rounded clasts. Locality Åtangen. (f) Intensive scapolitisation of an evolved breccia with amphibole veins, amphibole + scapolite matrix, and rounded clasts. Locality Åtangen. (g) Brecciated amphibolite with scapolite veins undergoing flattening. Locality Åtangen. (h) Foliated scapolite-bearing amphibolites. Locality Åtangen.

The clinopyroxene-bearing albitite and its melanocratic layers show replacement to rutile-bearing, light pink, fine-grained albitite. The contact to the enveloping amphibolite unit is associated with a greenish-grey transformation of mafic phases. Analysed amphiboles show edenitic, pargasitic, and actinolitic compositions. In addition, Dahlgren et al. [32] report dolomite-dominated deposits in this area with veining and brecciation of the metagabbro and amphibolites. 


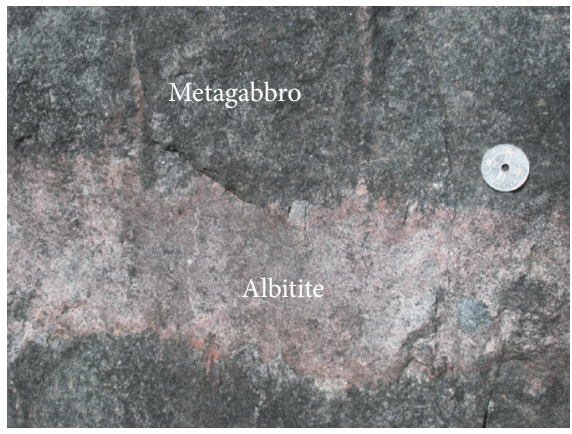

(a)

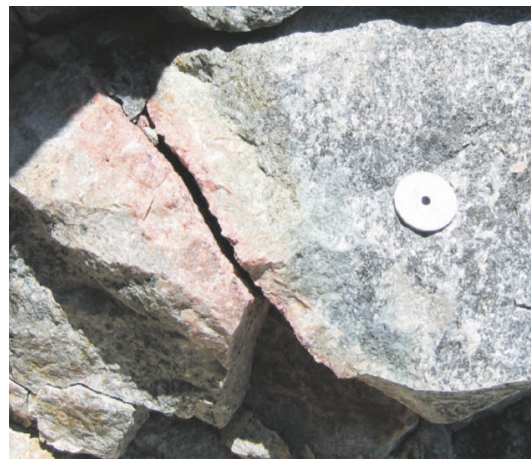

(c)

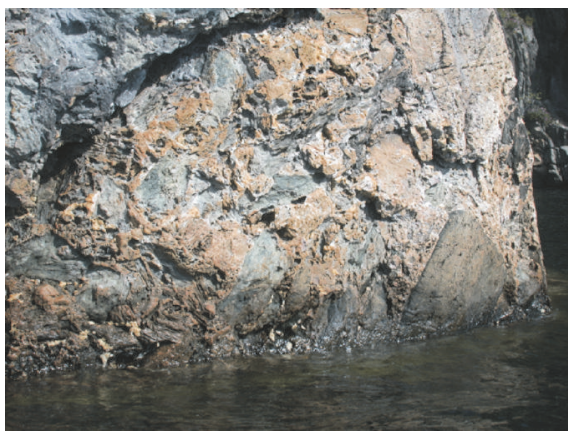

(e)

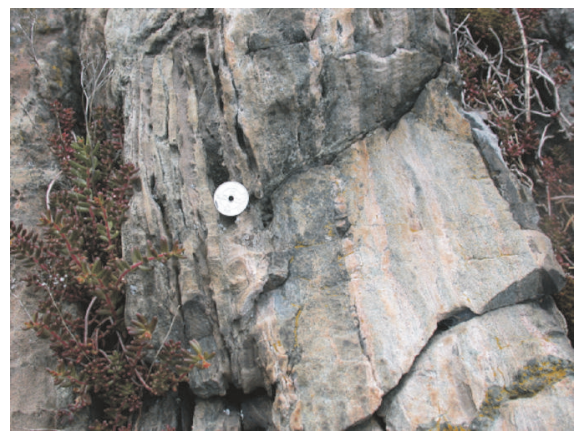

(g)

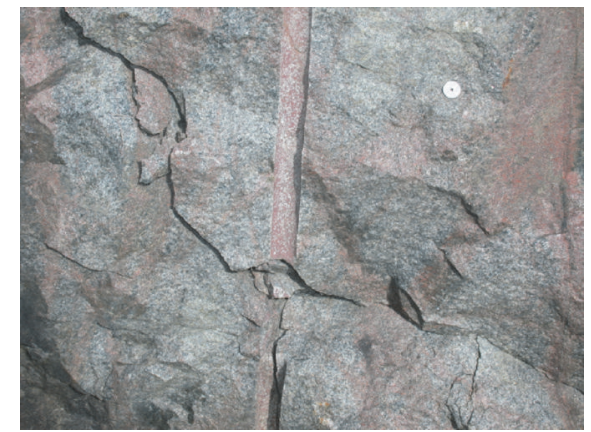

(b)

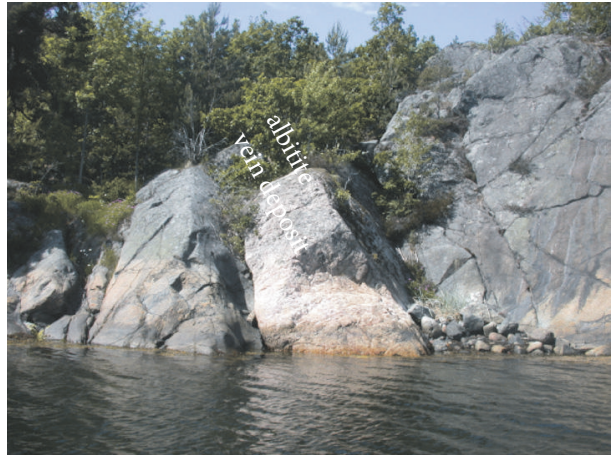

(d)

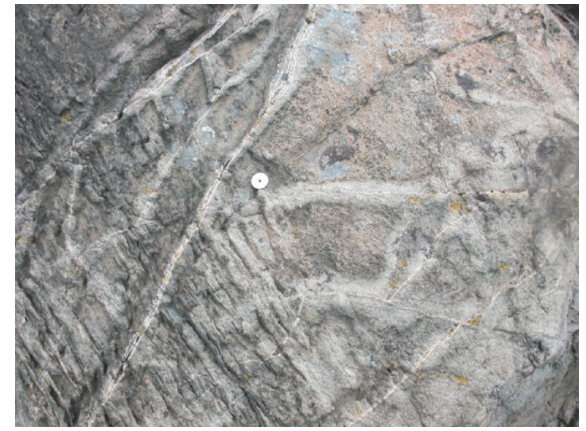

(f)

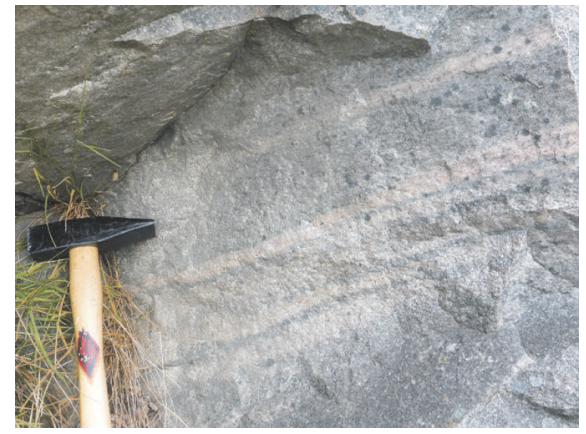

(h)

FIGURE 3: Field photos of albitites and dynamic albitisation. (a) Albitisation vein in metagabbro transforming the dark mafic rock to nearly pure albite. Locality Ringsjø. (b) Albitisation (red color) of tonalite (light color) along veining. Locality Fesettjern, Ringsjø area. (c) Vein albitisation (red color) causing chloritisation (greenish color) of scapolite metagabbro (dark grey). Locality Ringsjø. (d) Carbonate-rich albitite forming an approximate 5-metre wide vein deposit in the metagabbro. Locality Langøy. (e) Breccia containing clasts of albitised metagabbro in the matrix of a carbonate-rich albitite deposit. Field of view is approximately four metres wide. Locality Langøy. (f) Albitisation of metagabbro along veining with transformation to foliated albitic felsites. Locality Langøy. (g) Foliated albititic felsites with alternating light carbonatealbite and green-grey chlorite-schist bands. Locality Langøy. (h) Banded clinopyroxene-bearing albitite. Locality Åtangen. 


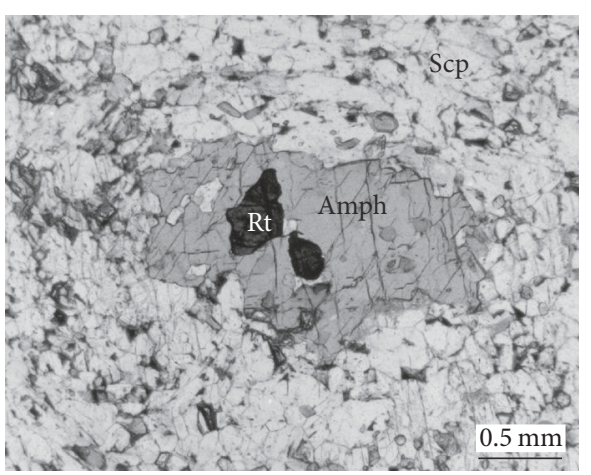

(a)

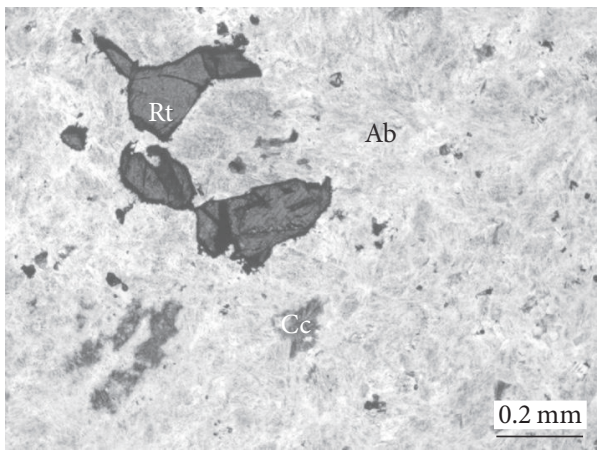

(c)

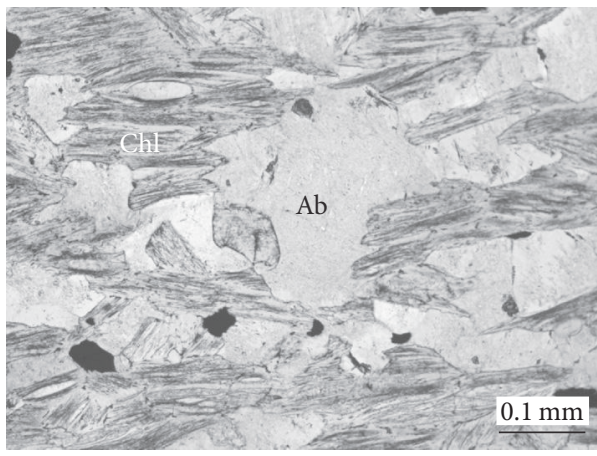

(e)

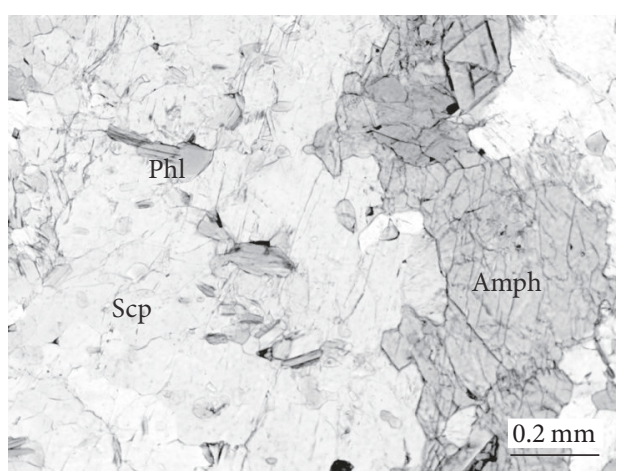

(b)

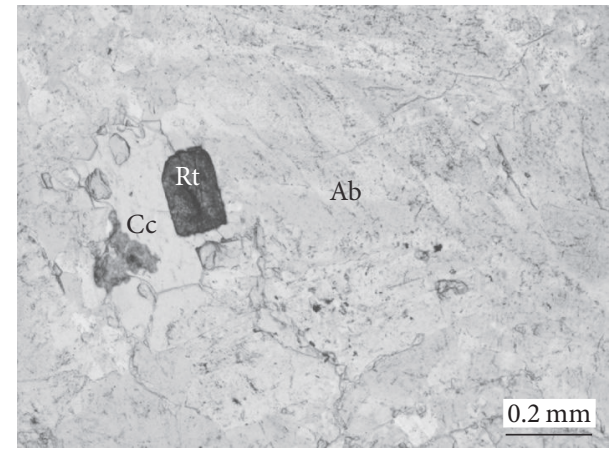

(d)

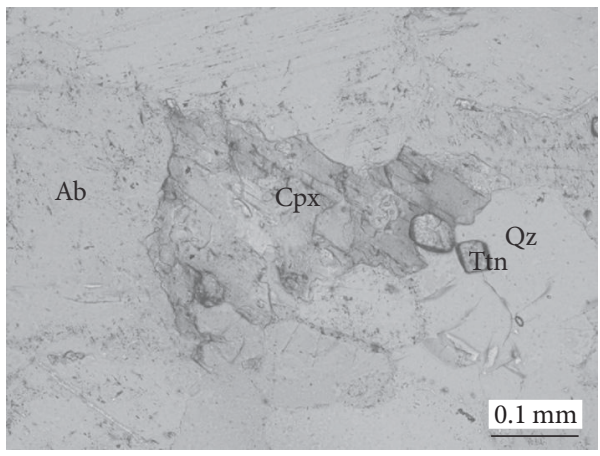

(f)

FIGURE 4: Photomicrographs of representative petrography from metasomatised rocks (mineral abbreviations after Whitney and Evans [36]). (a) Scapolite metagabbro dominated by scapolite and amphibole with accessory rutile. Locality Ødegården Verk, sample 2Ø91.45. (b) Phlogopite-bearing scapolite metagabbro. Locality Langøy, sample AE46. (c) Rutile-bearing albitite from veining in an amphibolite. Locality Ringsjø, sample AE10A. (d) Calcite-rich albitite (albitite vein deposit) with rutile. Locality Langøy, sample AE93. (e) Banded albitite felsites with the foliation outlined by chlorite. Locality Langøy, sample AE87. (f) Clinopyroxene-bearing albitite with quartz and titanite. Locality Storkollen, sample AE96.

4.2. Petrography and Mineral Chemistry. Petrography and mineral chemistry of the metasomatic rocks have been described in detail by Engvik et al:: albitisation of granitoid [35], scapolite metagabbro and vein-related albitisation of mafic rock [20,29], albite-carbonate-rich deposits and albitic felsites [23], and scapolite metagabbro, clinopyroxenebearing albitite, and rutile-albitite [50].

4.2.1. Scapolite Metagabbro. The scapolite metagabbro is dominated by a Cl-rich marialitic scapolite $\left(\mathrm{Me}_{19-42}\right)$ and edenitic, pargasitic, and actinolitic amphibole $(\mathrm{Mg} \#=$ 0.79-0.87; $\mathrm{Cl}<0.24$ a.p.f.u.), and it locally contains a high phlogopite content $(\mathrm{Mg} \#<0.95)$ (Figures 4(a)-4(b)). The Ti-bearing phase is normally rutile. At Ødegården Verk, the scapolite metagabbro shows in addition a high chlorapatite and enstatite $\left(\mathrm{En}_{95-96} \mathrm{Fs}_{3-4}, \mathrm{Mg} \#=0.94-0.95\right)$ content. Sapphirine is formed during replacement of the former plagioclase by scapolite [34].

Scapolite from the Kragerø area is Cl-rich, that is, 0.80-0.97 a.p.f.u. (marialite), although $\mathrm{Cl}$ values down to 0.69 a.p.f.u. have been measured. It is low in $S(S<$ 0.07 a.p.f.u.), combined with the measured $\mathrm{Cl}-$ level, indicating a C-content varying up to 0.4 a.p.f.u. $[20,50]$. Scapolite in metagabbros is replaced by albite and analcime during 
albitisation, releasing $\mathrm{CO}_{2}$ and precipitating calcite (see Engvik et al. [50], Figures 4(a)-4(d)).

4.2.2. Rutile-Bearing Albitite. Rutile-bearing albitite forms as vein replacement in mafic (including scapolite-bearing rocks) and granitoid protoliths, and pervasive albitisation results in large-scale albitite bodies (Figure 1(b)). Albitite is composed of nearly pure albite $\left(\mathrm{Ab}_{98-99}\right)$ with accessory rutile, formed from a mafic protolith, and occurs in extreme transformed localities (Figure 4(c)). In the protolith-albitite transition zones, remnants after mafic phases are present in variable amounts. Partly transformed amphibole remnants (edenitepargasite-actinolite; $\mathrm{Mg \#}=0.81-0.88)$, chlorite $(\mathrm{Mg \#}=$ $0.82-0.87$ ), calcite, and minor prehnite and pumpellyite are observed locally. Albitite, formed from a granitoid protolith, is dominated by albite $\left(A b_{99}\right)$, quartz, with rutile as the accessory Ti-phase, and minor chlorite $(\mathrm{Mg \#}=0.82)$, epidote, and calcite locally.

4.2.3. Carbonate-Rich Albitite and Albitite Felsite. The carbonate-rich albitite consists of fine to medium grains of near end-member albite $\left(\mathrm{Ab}_{97-100}\right)$, calcite, and dolomite (Figure $4(\mathrm{~d})$ ). Minor quartz and chlorite are present with rutile and Fe-oxides as accessories. The albitite host clasts consist of mafic, greenish-grey, fine-grained, and retrograded metagabbro, partly replaced by albitite and characterised by a higher content of chlorite and Fe-oxide. In the related, banded, albite-rich felsitic schist, the light bands are composed of fine-grained albite, calcite, chlorite $(\mathrm{Mg} \#=$ 0.85-0.89), and amphibole. The darker bands also contain clinopyroxene and some phlogopite $(\mathrm{Mg} \#=0.82)$, with rutile, apatite, zircon, and magnetite as accessory phases. In addition to the banding, reflected by modal variation, a parallel fabric is defined by planar-oriented phlogopite and chlorite (Figure 4(e)).

4.2.4. Clinopyroxene-Bearing Albitite. The clinopyroxenebearing albitite is a leucocratic granoblastic, fine- to mediumgrained rock, dominated by albite $\left(\mathrm{Ab}_{94-96}\right)$ and quartz, with minor amounts of clinopyroxene $\left(\mathrm{En}_{30-36} \mathrm{Fs}_{12-23} ; \mathrm{Na}=\right.$ $0.12-0.15$ a.p.f.u.; $\mathrm{Mg} \#=0.57-0.75$ ); (Figure 4(f)). Amphibole (actinolite or magnesiohornblende; $\mathrm{Mg \#}=0.67-0.79$ ) occurs locally related to, and partly replacing, clinopyroxene in melanocratic layers. The albitite is relatively rich in titanite and has in addition apatite and zircon as accessory minerals. Its replacement to rutile-bearing albitite is petrographically evident by formation of a porous albite chessboard $\left(\mathrm{Ab}_{98-100} \mathrm{An}_{0-2}\right)$, by replacement of clinopyroxene by chlorite $(\mathrm{Mg \#}<0.80)$ and calcite, and by replacement of titanite by aggregates of rutile + calcite + quartz.

4.3. Whole Rock Geochemistry. Whole rock geochemical data from the gabbro/metagabbro and tonalite protolith, together with the metasomatic scapolite-bearing metagabbro and albitites, are presented in Table 2 and Figure 5. While scapolite metagabbro has a gabbro protolith, the albitites are derived from a variety of rocks including a gabbro or scapolite metagabbro protolith for the samples with $\mathrm{SiO}_{2}<70$, whereas for albitites with $\mathrm{SiO}_{2}>70$ a granitoid or unknown protolith is inferred (Table 2). For the major elements, systematic geochemical changes are seen for the elements $\mathrm{Na}, \mathrm{Ca}, \mathrm{Fe}$, and $\mathrm{Mg}$ in the metasomatic rocks compared to the protoliths. For scapolite metagabbro and albitite derived from gabbro, $\mathrm{Na}_{2} \mathrm{O}$ increases and $\mathrm{CaO}$ decreases with increasing $\mathrm{SiO}_{2}$ (Figures $5(\mathrm{a})$ and $5(\mathrm{~b}))$. For a specific content of $\mathrm{SiO}_{2}$, the $\mathrm{Na}_{2} \mathrm{O}$ is higher for the scapolite metagabbro than for the albite, which reflects that the $\mathrm{Na}: \mathrm{Si}$ ratio in marialite is $2: 1$, while the same ratio for albite is $1: 1$. We regard the two trends, defined by increasing $\mathrm{Na}_{2} \mathrm{O}$ with increasing $\mathrm{SiO}_{2}$ for scapolite metagabbro and albitites with $\mathrm{SiO}_{2}<70$, to represent increasing degree of scapolitisation and albitisation. $\mathrm{Fe}_{2} \mathrm{O}_{3}$ (Figure 5(c)) is generally lower in the scapolite metagabbro compared to the gabbro/metagabbro and shows especially low values in the albitites. MgO (Figure 5(d)) decreases with increasing $\mathrm{SiO}_{2}$ for both albitite and scapolite metagabbros. An increase of $\mathrm{P}_{2} \mathrm{O}_{5}$ with increasing degree of scapolitisation (increasing $\mathrm{SiO}_{2}$ ) is apparent for the scapolite metagabbros, while for albitites the $\mathrm{P}_{2} \mathrm{O}_{5}$ decreases with albitisation (Figure 5(e)). The concentration of the trace elements $\mathrm{Zn}$ and $\mathrm{Cu}$ (Figures 5(f) and 5(g)) decreases with increasing degree of scapolitisation and both elements are below $15 \mathrm{ppm}$ for all albitites, while one of the gabbro samples contains around $90 \mathrm{ppm}$ for both $\mathrm{Zn}$ and $\mathrm{Cu}$ (Table 2). Bromine which is absent in the protolith rocks increases with increasing degree of scapolitisation up to a level of $80 \mathrm{ppm}$, while this element is below the detection limit in the albitites (Figure 5(h)). No analyses of $\mathrm{Cl}$ are available, but we assume, based on the mineralogical evolution and mineral chemistry, that $\mathrm{Cl}$ must parallel the evolution of $\mathrm{Br}$ at a much higher level. Like $\mathrm{P}_{2} \mathrm{O}_{5}, \mathrm{TiO}_{2}$ increases with increasing degree of scapolitisation (Figure 5(i)). Albitites with low $\mathrm{SiO}_{2}$ values contain the highest $\mathrm{TiO}_{2}$ content (ca 4 wt\%), while increasing the degree of albitisation apparently results in decreasing the $\mathrm{TiO}_{2}$ content. Vanadium, an element that typically follows $\mathrm{Ti}$, displays a clear increase with degree of scapolitisation and a reduction during progressive albitisation (Figure 5(j)). For most of the metasomatised samples analysed, there is a negative correlation between $\mathrm{TiO}_{2}$ and $\mathrm{Fe}_{2} \mathrm{O}_{3}$, while for the gabbro an overall positive correlation between these two oxides exists (Figure $5(\mathrm{k})$ ). $\mathrm{TiO}_{2}$ values up to $4.31 \mathrm{wt} \%$ are found in some of the scapolite metagabbros and albitites.

\section{Stable Isotopic Compositions}

Mineral separates from the scapolite metagabbro and albitites have been analysed for the stable isotopes of $\mathrm{O}\left(\delta^{18} \mathrm{O}\right)$, $\mathrm{H}(\delta \mathrm{D})$, and $\mathrm{C}\left(\delta^{13} \mathrm{C}\right.$; Table 3$)$. Albite separates from different types of albitites, quartz separates from clinopyroxene-bearing albitites, calcite separates from carbonate-rich albitite, and scapolite separates from scapolite metagabbros have been analysed with respect to $\delta^{18} \mathrm{O}$. The albite, calcite, and scapolite are presumed to have formed during metasomatism, while the quartz equilibrated with these minerals during the same event. The stable isotopic composition of these minerals should give constraints on the infiltrating fluid chemistry, but $\mathrm{O}$ in the silicate crystal structure should also retain information regarding the origin of the rock. 

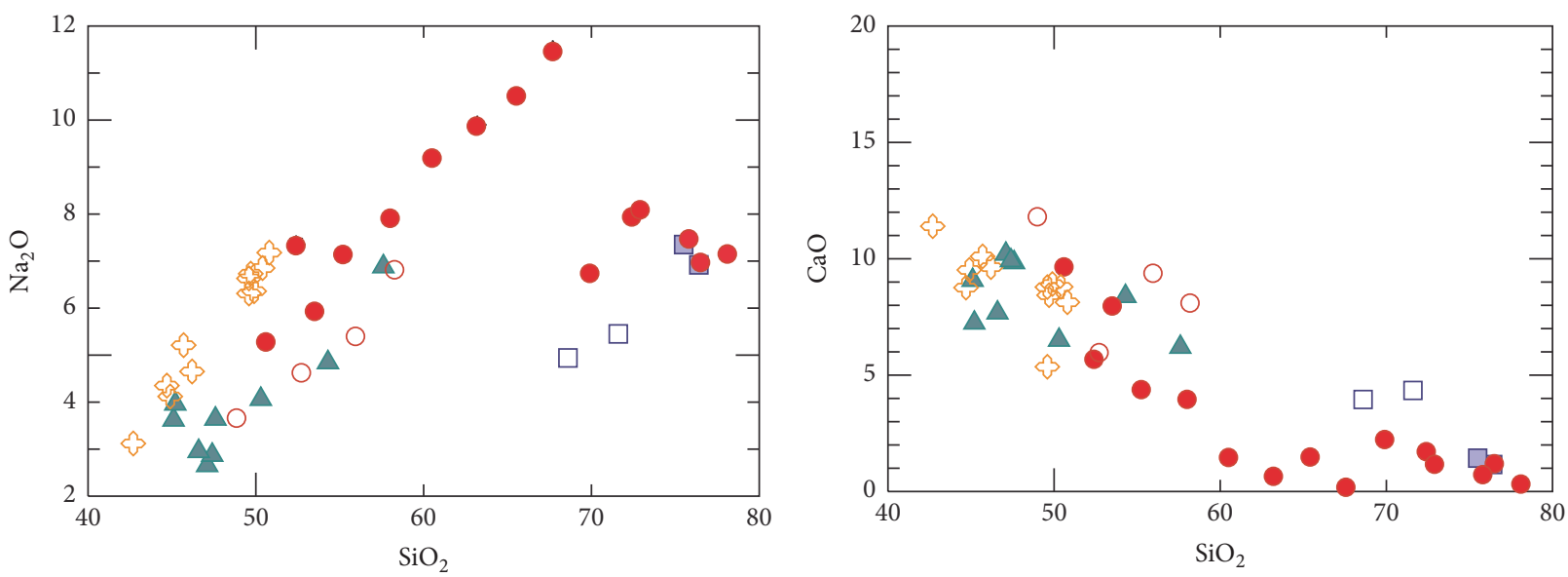
Gabbro/metagabbro
- Albitite
$\square$ Tonalite

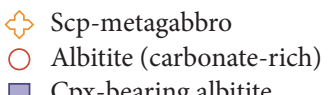
$\square$ Cpx-bearing albitite

(a)

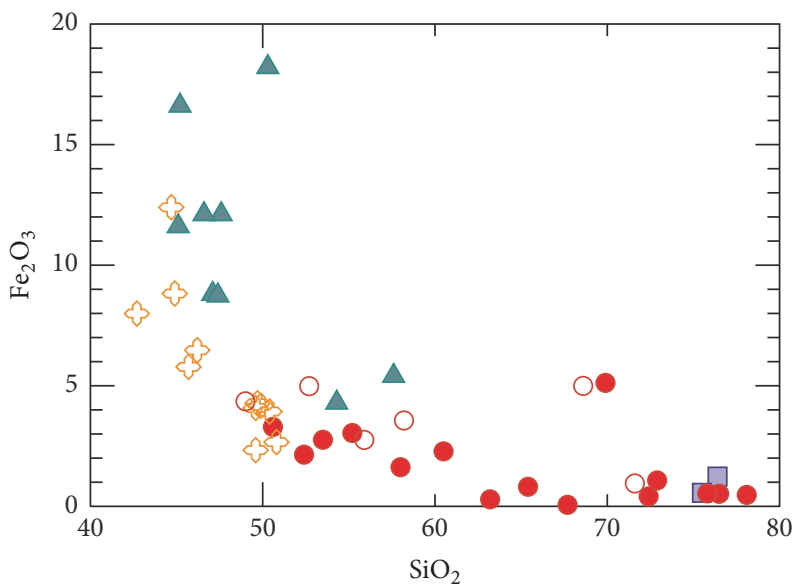
Gabbro/metagabbro
Albitite
\{ Scp-metagabbro
Albitite (carbonate-rich)
$\square$ Tonalite
$\square$ Cpx-bearing albitite

(c)

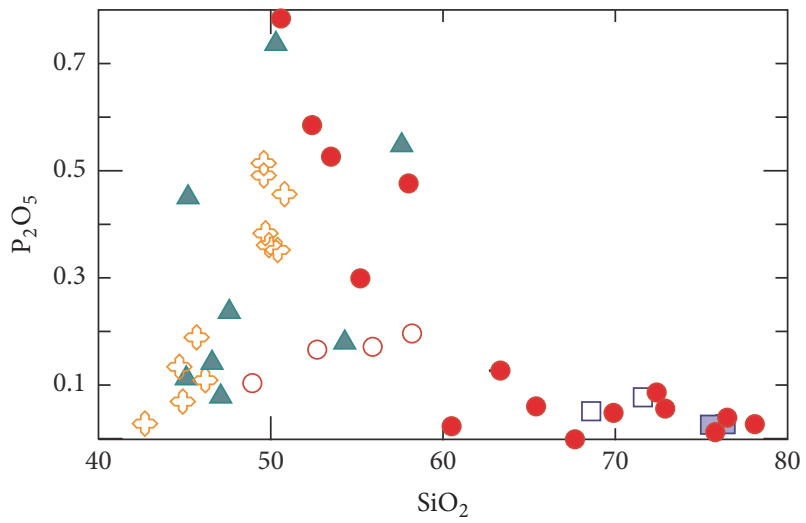

Gabbro/metagabbro

Albitite

\{3 Scp-metagabbro

$\square$ Tonalite

Albitite (carbonate-rich)

$\square$ Cpx-bearing albitite
Gabbro/metagabbro
Albitite
\&3 Scp-metagabbro
Albitite (carbonate-rich)
Tonalite
$\square$ Cpx-bearing albitite

(b)

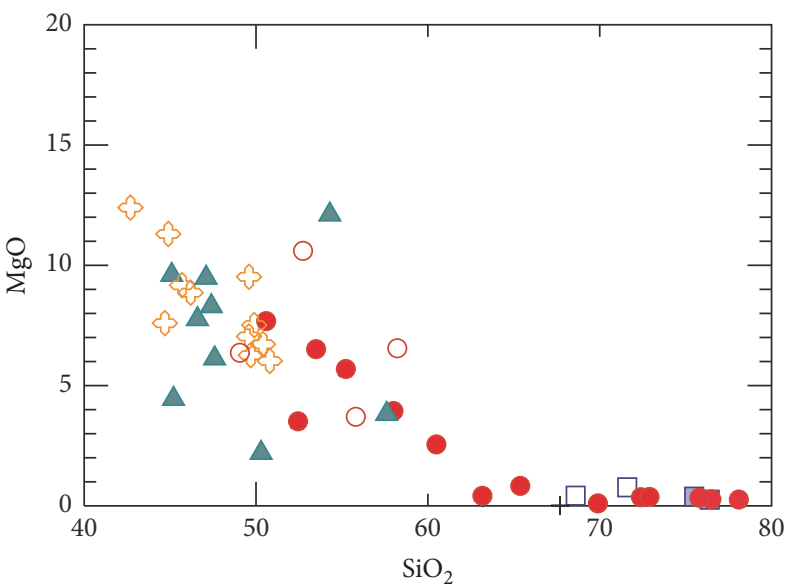

$\Delta$ Gabbro/metagabbro \& Scp-metagabbro

Albitite

Albitite (carbonate-rich)

$\square$ Tonalite

$\square$ Cpx-bearing albitite

(d)

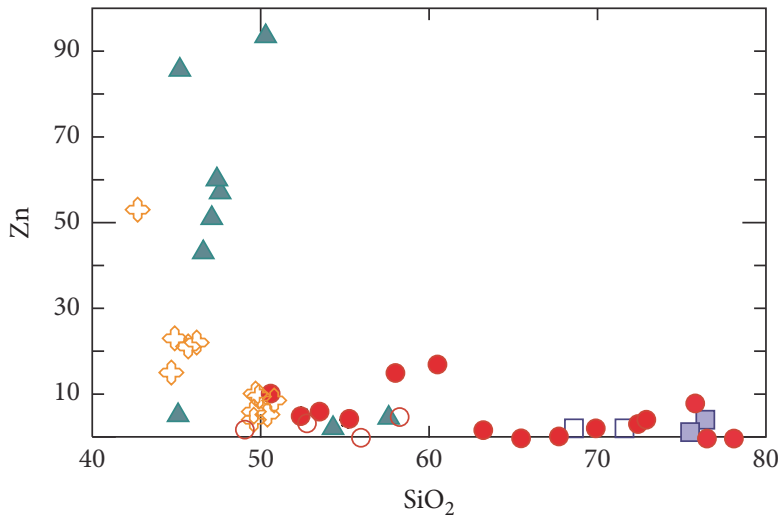
$\triangle$ Gabbro/metagabbro
Scp-metagabbro
- Albitite
$\bigcirc$ Albitite (carbonate-rich)
$\square$ Tonalite
$\square$ Cpx-bearing albitite

(e)

(f)

Figure 5: Continued. 


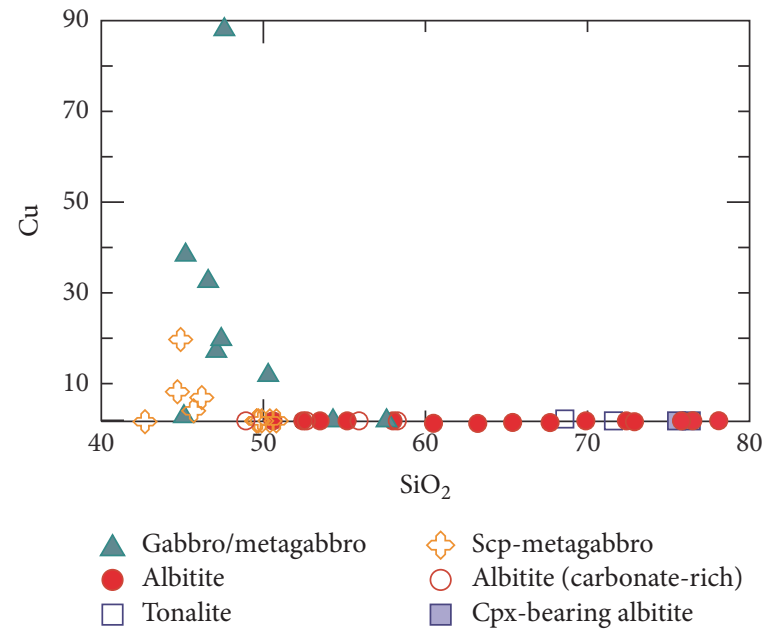

(g)

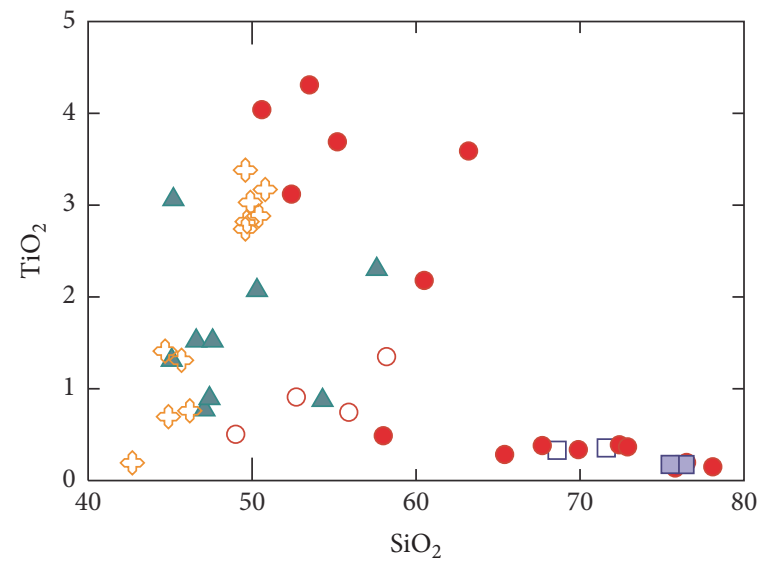
$\triangle$ Gabbro/metagabbro
Albitite
$\square$ Tonalite

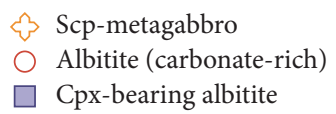

(i)

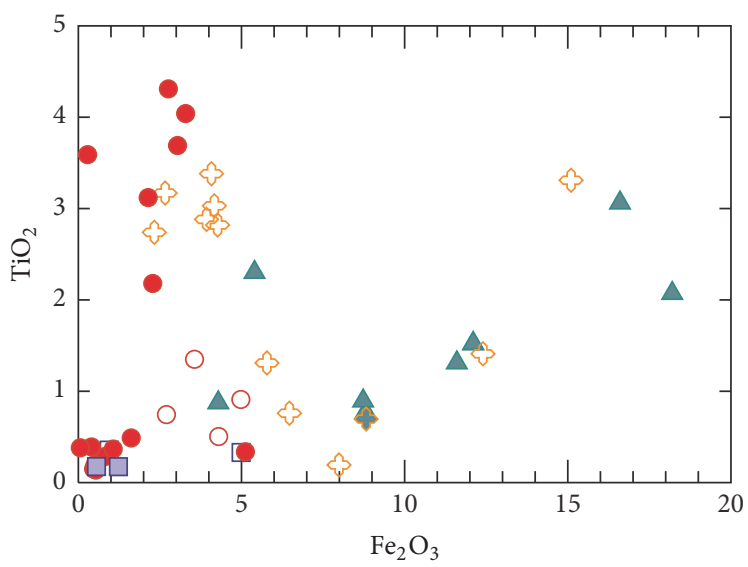
A Gabbro/metagabbro
Albitite
\{3 Scp-metagabbro
Tonalite
Albitite (carbonate-rich)
$\square$ Cpx-bearing albitite

(k)

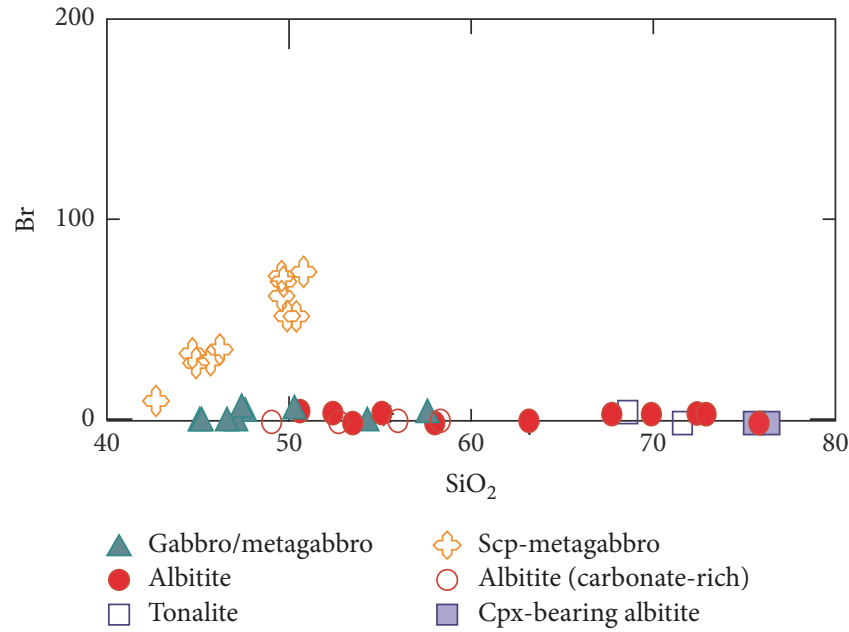

(h)

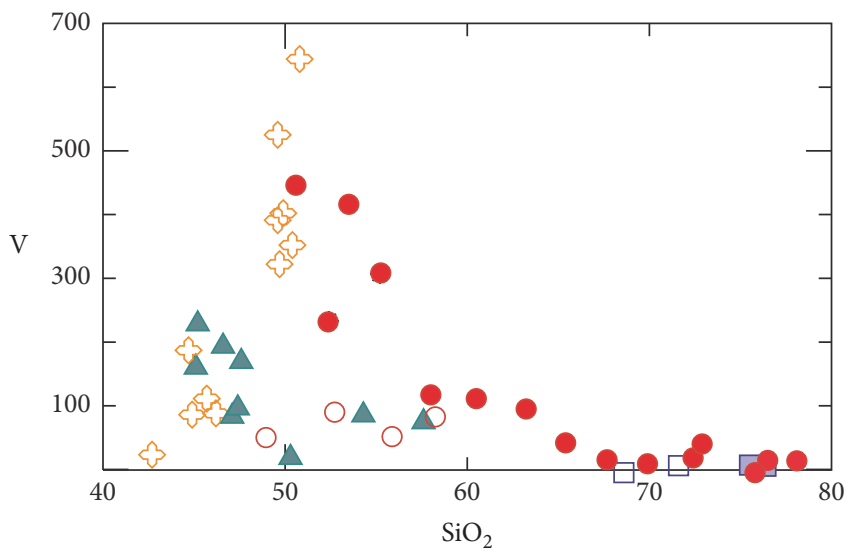
Gabbro/metagabbro
\&3 Scp-metagabbro
Albitite
Tonalite
Albitite (carbonate-rich)
$\square$ Cpx-bearing albitite

(j)

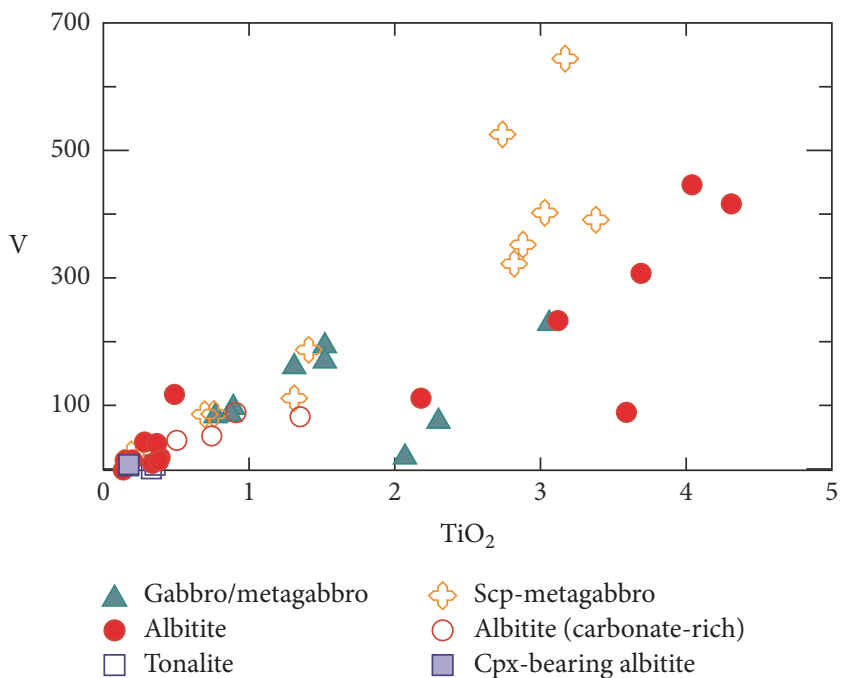

(1)

Figure 5: Plots of whole rock geochemical data: (a) $\mathrm{Na}_{2} \mathrm{O}-\mathrm{SiO}_{2}$; (b) $\mathrm{CaO}-\mathrm{SiO}_{2}$; (c) $\mathrm{Fe}_{2} \mathrm{O}_{3}-\mathrm{SiO}_{2}$; (d) $\mathrm{MgO}_{-} \mathrm{SiO}{ }_{2}$; (e) $\mathrm{P}_{2} \mathrm{O}_{5}-\mathrm{SiO}_{2}$; (f) $\mathrm{Zn}-\mathrm{SiO}{ }_{2}$; (g) $\mathrm{Cu}-\mathrm{SiO}_{2}$; (h) $\mathrm{Br}-\mathrm{SiO}_{2}$; (i) $\mathrm{TiO}_{2}-\mathrm{SiO}_{2}$; (j) $\mathrm{V}-\mathrm{SiO}_{2}$; (k) $\mathrm{TiO}_{2}-\mathrm{Fe}_{2} \mathrm{O}_{3}$; and (l) $\mathrm{V}-\mathrm{TiO}_{2}$. 
In addition, the $\delta \mathrm{D}$ composition of amphibole separates from the scapolite metagabbro is presented. The amphibole crystallized during the metasomatic alteration of the dry gabbro by the infiltration of an external fluid [20]. Consequently, the $\delta \mathrm{D}$-values give direct information on the chemistry of the metasomatising fluid. Carbon, in the form of $\mathrm{CO}_{2}$, was also supplied externally during the metasomatic event resulting in the formation of calcite, which was analysed for $\delta^{13} \mathrm{C}$.

Albite mineral separates from the Ringsjø-Ødegården Verk area give $\delta^{18} \mathrm{O}_{\mathrm{SMOW}}$ values of 5.1 to $8.4 \%$ for samples of albitite originating from a mafic/gabbro protolith and 8.5 to $10.8 \%$ o for samples originating from a granitoid/tonalite. Albite, from carbonate-bearing albitite samples from Langøy, gives a $\delta^{18} \mathrm{O}_{\text {SMOw }}$ of 5.5 to $7.0 \%$. Albite from a clinopyroxene-bearing albitite in the Åtangen-Storkollen area yields a $\delta^{18} \mathrm{O}_{\text {SMOW }}$ of 10.8 to $11.1 \%$, while quartz from the same samples gives a $\delta^{18} \mathrm{O}_{\text {SMOW }}$ of 11.5 to $11.6 \%$. Scapolite separates from a scapolite metagabbro sampled at the Ødegården Verk and Ringsjø localities give $\delta^{18} \mathrm{O}_{\text {SMOW }}$ values in the range of 7.4 to $10.6 \%$. Calcite from different albitites shows a wide range in $\delta^{18} \mathrm{O}_{\text {SMOW }}$ between 3.4 and $12.4 \%$, but with a quite consistent $\delta^{13} \mathrm{C}$ of -4.6 to $-6.0 \%$ (Figure 6). Amphibole separates from the same scapolite metagabbro samples yield $\delta^{18} \mathrm{O}_{\text {SMOW }}$ from 4.3 to $6.7 \%$ and $\delta \mathrm{D}_{\text {SMOW }}$ of -84 to $-50 \%$.

\section{Discussion}

6.1. Metasomatism and Mineralisation. Metasomatism is extensive in south Norway [18, 23]. Earlier work in the Bamble lithotectonic domain has shown that scapolitisation transforms mafic rocks into scapolite metagabbros by infiltration of $\mathrm{Cl}-\mathrm{Mg}$-rich solutions and that albitites form from both mafic and granitoid protoliths by Na-rich solutions [20, 35]. As expected, $\mathrm{Na}_{2} \mathrm{O}$ increases and $\mathrm{CaO}$ decreases during albitisation. Addition of albite to a gabbroic protolith will dilute the nonadded elements in equal proportion. Although the overall trend displayed by Figure 5 can be explained by addition of albite and scapolite to a gabbroic protolith, the $\mathrm{TiO}_{2}-\mathrm{Fe}_{2} \mathrm{O}_{3}$ relationship shown in Figure 5(k) strongly indicates that addition of albite and scapolite alone cannot explain the chemical evolution displayed and that other elements must have been mobile. The strong reduction in $\mathrm{Fe}_{2} \mathrm{O}_{3}$ suggests that this oxide is removed during albititisation and to some extent during scapolitisation. The measured variation in $\mathrm{Br}$ and $\mathrm{Cl}$ which is assumed to parallel $\mathrm{Br}$ suggests that these elements are added during the scapolitisation but were removed from the rock during albitisation. The mineralogical evolution, where Cl-scapolite formed during scapolitisation and later broke down during albitisation, suggests that halogens will be present in the fluid also during albitisation and are available for complexing with metals (e.g., $\mathrm{Fe}, \mathrm{Cu}$, and $\mathrm{Zn}$ ). We suggest that such a complexing can explain the many ore deposits in the area and in particular the Langøy Fe-mines.

The Bamble lithotectonic domain is characterised not only by widespread metasomatic alteration, but also by a high density of mineral deposits (Geological Survey of Norway

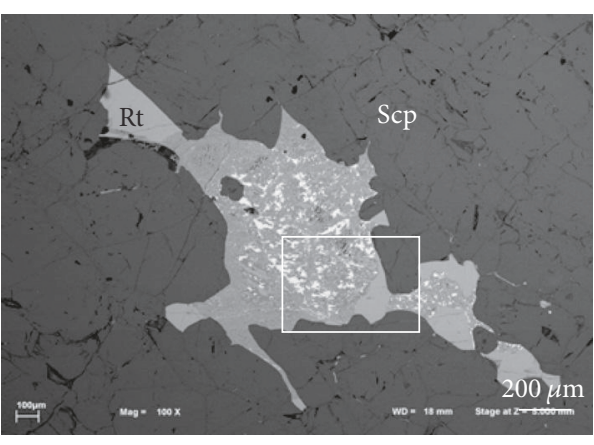

(a)

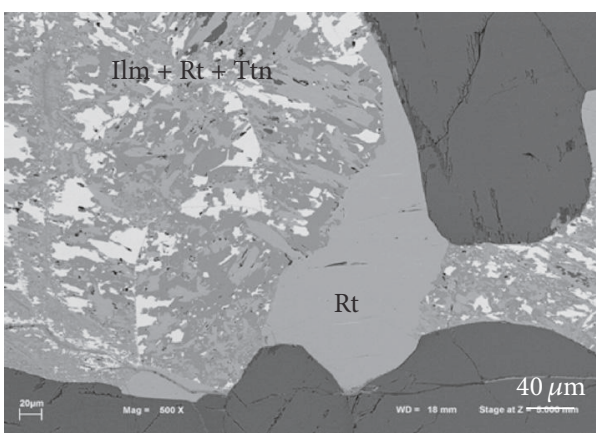

(b)

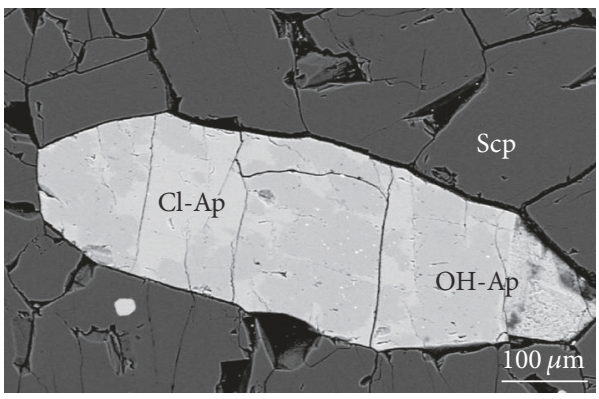

(c)

FIGURE 6: (a) Back-scattered electron (BSE) image of replacement of ilmenite by rutile in a scapolite metagabbro. Square indicates image in Figure 6(b). Sample 2Ø88.80, locality Ødegården Verk (photo: A. Korneliussen). (b) Detail of incomplete alteration of ilmenite (white) to rutile (light grey) and titanite (grey) (photo: A. Korneliussen). (c) BSE image of $\mathrm{Cl}$ and hydroxyapatite in scapolite metagabbro. Sample 2Ø78.20, locality Ødegården Verk.

Ore Database [24-26]). The high density of apatite and rutile deposits follows the regional distribution of metasomatic alteration in the Bamble lithotectonic domain [23]. While ilmenite is the main Ti-bearing mineral in the gabbro protolith, Ti occurs as rutile (Figures 6(a)-6(b)) and in amphibole ( $<0.34$ a.p.f.u.) and biotite ( $<0.69$ a.p.f.u.) within the scapolite metagabbro [20]. Replacement of ilmenite by rutile is illustrated in Figures 6(a)-6(b). During albititisation, biotite and amphibole break down and $\mathrm{Ti}$ is released as titanite [20,31]. The whole rock geochemical data (Figures 5(i) and 5(j)) illustrates that $\mathrm{TiO}_{2}$ and $\mathrm{V}$ increased during scapolitisation and decreased during albitisation. The high values of $\mathrm{TiO}_{2}$ in some of the albitites are probably inherited from the scapolite enrichment. $\mathrm{Fe}_{2} \mathrm{O}_{3}$ decreases during scapolitisation and 
albitisation and the $\mathrm{TiO}_{2}-\mathrm{Fe}_{2} \mathrm{O}_{3}$ relationships (Figure 5(k)) cannot be the result of pure dilution by adding albite and scapolite but suggest that $\mathrm{Fe}$ is removed.

The whole rock geochemistry in Figure 5(e) illustrates the $\mathrm{P}$, which is increased during scapolitisation and that the $\mathrm{P}$ resources at Ødegården Verk owe their existence to this event rather than the albitisation event which leads to a reduction of $\mathrm{P}$. This is in accordance with earlier works which show that scapolite metagabbros commonly have both a high apatite content in the Bamble lithotectonic domain and host vein-related apatite deposits (Figure 6(c)) [19, 28, 29]. Scapolitisation and albitisation are documented as having formed chlorapatite and hydroxyfluorapatite at Ødegården Verk in Bamble (Figure 6(c)) [19, 28, 29].

As discussed above, metasomatism of the gabbro causes extensive Fe-depletion (Figure 5(c)) [20]. In addition, the whole rock geochemistry shows that the concentration of $\mathrm{Cu}$ and $\mathrm{Zn}$ is lowered during the scapolitisation of the gabbro/metagabbro (Figures 5(f)-5(g)) and is nearly completely depleted during albitisation of the same protolith. The fluid mobilization of these elements could have caused the widespread occurrences of metal deposits in the Bamble lithotectonic domain [23]. Fe-oxide ores are present as hematite-carbonate veins in the rutile-rich albitites in the Kragerø area and are widespread in the Bamble lithotectonic domain $[23,58]$, as hematite-rich albitites, orthoamphibolehematite veins, and albite-magnetite veins. $\mathrm{Cu}-\mathrm{Zn}$-bearing base metal deposits are frequent in the Kragerø-Bamble area (Geological Survey of Norway Ore Database). The association of Fe-ores with albitites and altered granites has been reported worldwide, for example, as in magnetite-apatite deposits from the Lyon Mountain area, Adirondacks, New York, USA [67].

6.2. Stable Isotopic Results: Fluid and Rock Origin. The stable isotopic composition of silicate mineral separates can reflect the origin of both the rocks and the infiltrating fluid [68, 69]. It will retain information from the protolith phases, but, depending on the degree of alteration and replacement, the isotopic composition will undergo a shift during fluid infiltration. Oxygen is already present in significant concentrations in the silicate minerals. To shift the $\delta^{18} \mathrm{O}$ composition in a silicate mineral will require large amounts of infiltrating fluids. This must be the case for the albitite rocks in the Bamble lithotectonic domain, which have undergone complete alteration to a new mineralogy, involving large chemical changes $[20,23,50]$.

A $\delta^{18} \mathrm{O}_{\mathrm{SMOW}}$ composition of 5.1 to $8.4 \%$ is seen for the albite separates from albitite formed from a gabbroic protolith (Table 3). Results for albite from a carbonate-rich albitite deposited in metagabbro at Langøy fall in the same range. $\mathrm{A} \delta^{18} \mathrm{O}_{\text {SMOW }}$ composition of 8.5 to $10.8 \%$ is obtained for albite, which originated from a granitoid protolith in the Ringsjø-Ødegården Verk area. From a clinopyroxenebearing albitite in the Åtangen-Storkollen area, the albite gives a $\delta^{18} \mathrm{O}_{\text {SMOW }}$ composition of 10.8 to $11.1 \%$ and the quartz 11.5 to $11.6 \%$. The results from measured albitites from both mafic and tonalitic magmatic precursors are in accordance with the original values from such protoliths [70] coupled with the influence of a fluid with both a magmatic and seawater origin [69]. Depending on the temperature, the reported $\mathrm{O}$-isotopic signature could originate from a magmatic fluid, although a magmatic fluid would normally give a higher value. Seawater could explain the reported values since it could lower the isotopic ratio relative to the magmatic protolith values. As metasomatic fluid infiltration is often spatially inhomogeneous, this could possibly also explain variations in the resulting values. A meteoric water source can clearly be ruled out, as meteoric water would have led to a significantly lower $\delta^{18} \mathrm{O}_{\text {SMOw }}$ composition of about +2 to $-10 \%$. Mark and Foster [71] document a similar $\delta^{18} \mathrm{O}_{\text {SMOW }}$ composition associated with albitisation in the Cloncurry district, Australia, and concluded that it is due to magmatic processes.

Amphiboles in scapolite metagabbros were produced during fluid infiltration into the dry protolith gabbro [20, 29]. This implies that the $\mathrm{H}$-isotopic content of the amphiboles, in contrast to the $\mathrm{O}$-isotopes, will give more accurate information regarding the metasomatic fluid. The $\delta \mathrm{D}$-composition of the amphibole from the scapolite metagabbro generally varies between -50 and $-59 \%$ and is in accordance with an igneous precursor [70] infiltrated by magmatic or metamorphic $\mathrm{H}_{2} \mathrm{O}$ $[69,72]$. A hydrothermal saline solution would not affect the $\delta \mathrm{D}$-composition, as it will give similar $\delta \mathrm{D}$-values compared to magmatic and metamorphic fluids. Again, a meteoric water origin can be excluded as it would give significantly lower values for the $\delta \mathrm{D}$ composition down to -90 to $-140 \%$. The stable isotopic composition of scapolite-bearing rocks is known from Mary Kathleen, Queensland, Australia [73], where the scapolitisation is interpreted to have been caused by magmatic fluids, and the Greenville Province, Ontario, Canada [74], where scapolitisation was caused by metamorphic fluids originating from a carbonate source.

For the carbonate-rich albitite, the $\delta^{18} \mathrm{O}_{\text {SMOw }}$ values show values similar to silicate rocks, indicating a magmatic source for $\mathrm{C}$ (Figure 7). This is supported by the $\delta^{13} \mathrm{C}_{\mathrm{PDB}}$ values, which fall between -6.0 and $-4.6 \%$ and give signatures similar to those for carbonatitic magma. Our petrographic investigations show in addition that breakdown of scapolite during albitisation produces carbonate [50]. Dahlgren et al. [32] described vein deposited dolomite marbles giving $\delta^{18} \mathrm{O}=$ 9.6 to $10.7 \%$, $\delta^{13} \mathrm{C}=-8.5$ to $-6.2 \%$, and high ${ }^{87} \mathrm{Sr} /{ }^{86} \mathrm{Sr}$ ratios of 0.706 to 0.709 , which overlaps the values reported from these studies (Figure 6) and values from the Bamble hyperites [37] and vein carbonates [40]. Dahlgren et al. [32] suggested that the dolomite marbles were formed from hydrothermal solutions that were channeled into a large degassing zone, which now takes the form of a deformed, regional zone with hydrothermal dolomite deposits, albitites, apatite-veins, and widespread scapolitisation. These authors speculated that the fluids were derived from charnockite intrusions in the region.

As mentioned above, while metasomatism is able to significantly alter the chemical composition of the precursor rock, this alteration may vary spatially. This also applies to the isotope composition of the rocks. Probably this is due to varying temperatures as well as the different water/rock $(\mathrm{w} / \mathrm{r})$ ratios that caused the alteration. The variable oxygen isotope 


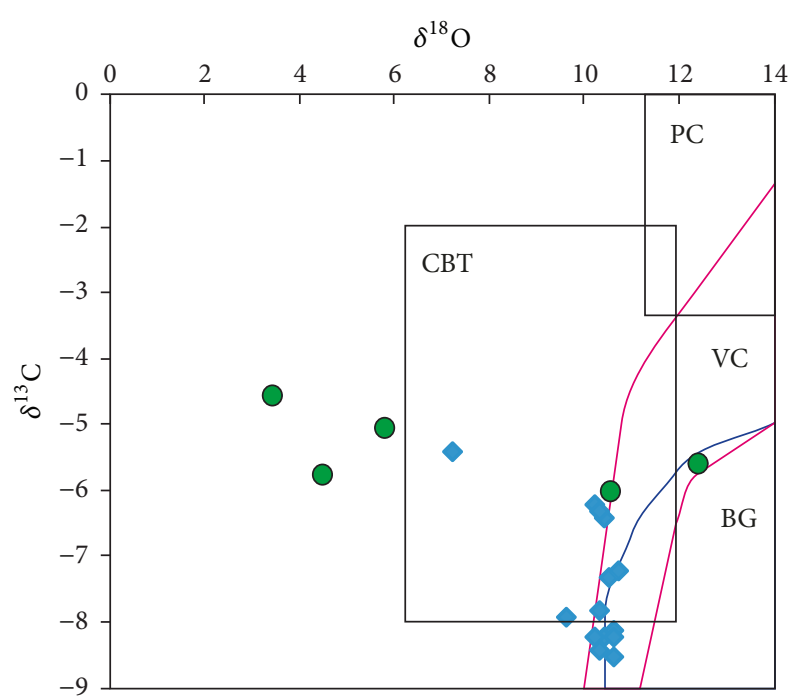

Figure 7: $\delta^{18} \mathrm{O}_{\text {SMOW }}$ versus $\delta^{13} \mathrm{C}_{\mathrm{PDB}}$ plot: circles indicate data from this study (Table 3 ) and diamonds indicate data from dolomite marble deposits/veins and a calcite + albite + quartz dike in the Kragerø area by Dahlgren et al. [32]. BG = Bamble hyperites [37]; $\mathrm{CBT}=$ world carbonatites [38]; $\mathrm{PC}=$ nonmetamorphic proterozoic carbonates [39]; $\mathrm{VC}=$ vein carbonate [40].

composition in all altered rock types from this study, in combination with relatively homogeneous $\mathrm{H}$ - and $\mathrm{C}$-isotope ratios, corroborates this assumption. Varying degrees of alteration, variable $T$, and variable $\mathrm{w} / \mathrm{r}$ ratios can produce isotopic signatures that reflect the values that we have measured and are shown in Table 3 . In addition, fluid compositions can also have been varied, even on a local scale, and scales of equilibrium might also have been local, regardless of the widespread regional occurrence of the metasomatic rocks.

For the sampled localities, Engvik et al. [20] reported a $\mathrm{Cl}$ - and B-rich environment, Sr-signatures in the scapolite with an initial ${ }^{87} \mathrm{Sr} /{ }^{86} \mathrm{Sr}$ ranging from 0.704 to 0.709 , and a regional distribution of lithologies, indicating that the fluid originated from evaporites that were mobilized during regional metamorphism. Our new data on the stable isotopic composition of the albitites and scapolite metagabbro support the interpretation that the original magmatic mafic and granitoid rocks were metasomatised by fluids reflecting a seawater origin or with a possible magmatic component. Depending on $T, w / r$, and the degree of alteration, both fluid types (seawater and magmatic) may lead to the same approximate pattern. What can be ruled out from the $\mathrm{H}$ and O stable isotope data is meteoric water as it would have led to significantly lower $\delta^{18} \mathrm{O}_{\text {SMOW }}$ and $\delta \mathrm{D}_{\text {SMOW }}$ values and also to different $\delta^{13} \mathrm{C}_{\mathrm{PDB}}$ values.

Other stable isotopic constraints in the Kragerø area of the Bamble lithotectonic domain support a mixture of magmatic and metamorphic fluid signatures coupled with seawater as being responsible for the metasomatism. Bast et al. [33] analysed B isotope compositions in tourmaline in order to constrain the possible sources of and the evolution of hydrothermal fluids. $\delta^{11} \mathrm{~B}$ values were found to range from -5 to $+27 \%$ o (relative to SRM-951), which suggests marine evaporites interlayered with continental detritus and pelagic clay as a possible $\mathrm{B}$ source reservoir. Negative $\delta^{11} \mathrm{~B}$ values were explained by the influence of pneumatolytic fluids associated with granitic pegmatites. Variations in $\delta^{11} \mathrm{~B}$ on a regional $\mathrm{km}$-scale, with small local variations, were explained by fluid infiltration during several generations of pulses.

Measurements of $\delta^{37} \mathrm{Cl}$, together with $\mathrm{F}, \mathrm{Cl}, \mathrm{Br}$, and I concentrations, were used to trace the metasomatic evolution of gabbroic bodies and to understand the interplay between localized and pervasive fluid flow $[27,30]$. The reported $\mathrm{Br} / \mathrm{Cl}$ and $\mathrm{I} / \mathrm{Cl}$ ratios $\left(3 \times 10^{-3}\right.$ and $\left.25 \times 10^{-6}\right)$ overlap with the range of ratios measured for marine pore fluids. The unaltered gabbro has $\delta^{37} \mathrm{Cl}$ values near $0 \%$ and a similar value is inferred for the infiltrating fluid. Minimally altered samples have negative $\delta^{37} \mathrm{Cl}$ values (average $=-0.6 \pm 0.1 \%$ ). $\delta^{37} \mathrm{Cl}$ values increase (up to $+1 \%$ ) with increasing evidence of fluid-rock interaction. Measured $\mathrm{Cl}$-stable isotope values of individual apatite grains are heterogeneous and range from -1.2 to $+3.7 \%$. High $\delta^{37} \mathrm{Cl}$ values are generally correlated with $\mathrm{OH}$-rich zones formed during fluid-aided metasomatic alteration of the chlorapatite, whereas low $\delta^{37} \mathrm{Cl}$ values, measured in the host chlorapatite, are interpreted to have been of magmatic origin.

6.3. Fluid Evolution. Changes in fluid conditions will affect the geochemical and mineralogical evolution during metasomatism. Fluids with a high $\mathrm{Mg}$ - and $\mathrm{Cl}$-content cause scapolitisation and phlogopite formation [20, 29], while Na-rich solutions cause albitisation [12, 20, 21, 23]. The replacement of scapolite by albite during the albitisation also releases $\mathrm{Cl}$ into the albitisation fluid. Metasomatism is enhanced by $\mathrm{Cl}$, which has been shown to be an effective ligand for transporting $\mathrm{Fe}[75,76]$. A high $\mathrm{CO}_{2}$ concentration in the fluid enhances carbonitisation [32]. The complexity and evolution of metasomatic fluids penetrating the Kragerø area can be explained by a series of different possible models, which include (1) phase separation of volatiles; (2) internal recycling; and (3) external infiltration, which are further expanded as follows.

(1) Phase Separation of Volatiles. Fluid composition evolves as a function of changes in physical conditions. A decrease in temperature will affect separation of volatiles into different phases $[77,78]$. Separation of hydrous and $\mathrm{CO}_{2}$-dominated fluid phases and brines could possibly explain the complex pattern in the spatial distribution of metasomatic rocks containing scapolite metagabbros, different varieties of albitites, and carbonate deposits in the Bamble lithotectonic domain.

(2) Internal Recycling. Albitisation can be controlled by internal recycling of fluids. The observed fluid composition and mineralogical reactions can be an effect of local replacement reactions. Mineral reactions can both release and consume fluid components and solutes, and dissolved elements in one reaction can be used in another reaction. The scapolite gabbro in the Kragerø area is composed mostly of major $\mathrm{Cl}-\mathrm{CO}_{2}$-dominated scapolite and $\mathrm{Ti}$-, $\mathrm{Fe}$-, and $\mathrm{Cl}$-bearing amphibole. During albitisation, both minerals break down 
and disappear as the rock is transformed into albitite. During these reactions, all $\mathrm{CO}_{2}, \mathrm{H}_{2} \mathrm{O}$, and $\mathrm{Cl}$ are released as fluids [50].

Breakdown of scapolite during albitisation results in albite, $\mathrm{CO}_{2}$, and $\mathrm{Cl}$ via the following reactions:

$$
\text { Scapolite }=2 \text { Albite }+2 \mathrm{CaO}+2 \mathrm{Al}_{2} \mathrm{O}_{3}+\mathrm{CO}_{2}+\mathrm{Cl}
$$

Here $\mathrm{CaO}$ and $\mathrm{CO}_{2}$ react to form calcite (Engvik et al. [50], Figures $4(\mathrm{a})-4(\mathrm{~d})$ ) and $\mathrm{Cl}$ can be reused as a ligand for metal complexing and transport. Also, replacement of rutile and scapolite by titanite releases $\mathrm{CO}_{2}$ and $\mathrm{Cl}$, whereas replacement of ilmenite and scapolite will also release Fe:

$$
\begin{aligned}
\text { 2Rutile }+ \text { Scapolite }= & 2 \text { Titanite }+\mathrm{Na}_{2} \mathrm{O}+3 \mathrm{Al}_{2} \mathrm{O}_{3} \\
& +4 \mathrm{SiO}_{2}+\mathrm{Cl}+\mathrm{CO}_{2}
\end{aligned}
$$

or

$$
\begin{aligned}
\text { 2Ilmenite }+ \text { Scapolite }= & 2 \text { Titanite }+\mathrm{Na}_{2} \mathrm{O}+3 \mathrm{Al}_{2} \mathrm{O}_{3} \\
& +4 \mathrm{SiO}_{2}+2 \mathrm{FeO}+\mathrm{Cl}+\mathrm{CO}_{2}
\end{aligned}
$$

Breakdown of amphibole during albitisation occurs in two stages:

$$
\begin{aligned}
\text { Amphibole }+3 \mathrm{H}_{2} \mathrm{O}= & \text { Chlorite }+ \text { Rutile }+\mathrm{FeO} \\
& +3 \mathrm{SiO}_{2}+\frac{1}{2} \mathrm{Al}_{2} \mathrm{O}_{3} \\
& +\frac{1}{2} \mathrm{H}_{2} \mathrm{O}+\frac{1}{2} \mathrm{CaO} \\
& +\frac{1}{4} \mathrm{Na}_{2} \mathrm{O}+\mathrm{Cl} \\
\text { Chlorite }= & 5\left(\mathrm{MgO}^{2} \mathrm{FeO}\right)+3 \mathrm{SiO}_{2} \\
& +\mathrm{Al}_{2} \mathrm{O}_{3}+4 \mathrm{H}_{2} \mathrm{O}
\end{aligned}
$$

Breakdown of the Cl-bearing amphibole and, subsequently, chlorite releases $\mathrm{H}_{2} \mathrm{O}$ and $\mathrm{Cl}$. Titanium from amphibole crystallizes as rutile [35], while Fe is either deposited as nanoinclusions of magnetite or hematite in the albite [79] or transported and deposited as ores associated with the albitite [23]. Excess $\mathrm{Na}, \mathrm{Al}$, and $\mathrm{Si}$ are used to produce albite or Al-Sirich phases [34], and the $\mathrm{Ca}$ is incorporated into the calcite.

(3) External Infiltration. Metasomatism can be controlled by an influx of external fluids. As discussed above, this work, combined with earlier isotopic studies in the Kragerø area $[20,27,30,32,33]$, indicates a mixture of magmatic and evaporitic/seawater signatures. This is in agreement with the regional lithological distribution, which consists of a mixed gneiss region with magmatic rocks and metasedimentary sequences $[43,80]$ metamorphosed during the late Sveconorwegian tectonometamorphic event $[20,50]$. Remobilized volatiles in sediments, possibly together with fluids derived during magmatic activity, were behind the regional metasomatism.

Engvik et al. [50] discuss the variety in lithology, mineral assemblages, and replacement related to albitisation, indicating changing physical conditions during albitisation, which possibly occurred in several stages over a longer time interval. Similar metasomatic processes have been also reported in other regions such as Australia [5, 81, 82], which have been affected by various tectonic processes and crustal movements. The scapolitisation of dry gabbro requires the infiltration of an external fluid. The breakdown of a scapoliteamphibole-dominated metagabbro to albitite could possibly contribute a substantial amount of the necessary fluids. The question as to whether metasomatism occurred in an open or closed system therefore depends on the scale, that is, if we regard the metagabbro rim zone capable of producing reactive solutions, which cause local albitisation in a closed system, or if the large-scale Bamble lithotectonic domain can be considered as a closed system, including both magmatic and metasedimentary sequences.

6.4. On the Dynamics of Fluid Infiltration. As described above, scapolitisation and albitisation have occurred not only as static replacement of rocks, but also throughout those parts, which consist of dynamic deformed veining, breccias, and foliated schists. Fluid infiltration and metasomatic replacement both occur as a pervasive replacement of larger rock volumes as observed in the scapolitisation of gabbros. In addition, a high fluid pressure will cause fracturing, which channelizes the fluids, resulting in metasomatism that is widespread in a brittle deformed structure as single veins, networks of veins, and breccias (Figures 2 and 3) resulting in structurally complex albitites and scapolite-bearing rocks. The reported local banded structure in scapolite metagabbros and albitites is interpreted to have been caused by veins (Figures 2(b)-2(d)) produced during metasomatic infiltration. A localized, high fluid pressure, resulting in brecciation of host rock, has been mapped out with both a scapolite-filling (Figures $2(\mathrm{e})-2(\mathrm{~g})$ ) at Åtangen and an albitite filling (Figures 3(e)-3(f)) at Langøy. The brittle fracturing and brecciation structures show a progressive deformation into the foliated schist. Here, the brecciated rocks are surrounded by scapolitebearing schists and amphibolites (Figure $2(\mathrm{~h})$ ) or albitedominated chlorite schists (Figure 4(e)) and carbonate-rich albitic felsites/schists (Figures 3(f)-3(g)). In addition, the role of deformation, as well as existing lithological contacts and lineaments, will affect the spatial distribution of the metasomatic rocks. Concurrent metasomatic infiltration and deformation caused a progression of the resulting foliation into the major regional structure, a process which was synchronous with a regional tectonometamorphic event.

Formation of metasomatic scapolite metagabbros in the Kragerø area is constrained at 600 to $700^{\circ} \mathrm{C}$ at mid-crustal levels [19]. Formation of the clinopyroxene-bearing albitite in the Kragerø area is calculated to $410-420^{\circ} \mathrm{C}$ by Engvik et al. [50], while Mark and Foster [71] constrain similar albitites to $450-550^{\circ} \mathrm{C}$ from the Cloncurry district in Australia [71]. The local presence of prehnite, pumpellyite, and analcime indicates a low-grade albitisation event at temperatures < $350^{\circ} \mathrm{C}$. The tectonometamorphic setting indicates that the albitisation processes occurred over a time span at middle to upper crustal levels. Although the scapolitisation conditions refer to a ductile crustal regime, fracturing and formation 
of breccias caused by high fluid pressure [83-85] have been described as a precursor stage for ductile deformation in the lower crust $[86,87]$. A variation in fluid pressure can possibly explain the change between brittle and ductile deformation during metasomatism. The ductile formation of foliation in both the scapolite metagabbro and scapolite-bearing amphibolites at Åtangen, following scapolite-cemented brecciation, and similar formation of foliated albitic felsites and chlorite schists at Langøy, illustrate that the deformation changed from brittle to ductile during metasomatism. Both breccias and ductile rock fabrics are well known elsewhere in albitised and scapolitised crust $[5,20]$.

In the Kragerø area, single, metasomatised, large $\left(>1 \mathrm{~km}^{2}\right)$ albitites and scapolite metagabbro bodies have been mapped. These replacement zones, resulting from metasomatic infiltration, are widespread on the regional scale similar to features mapped in the Modum area [21]. Age dating of the metasomatism indicates that these processes were part of the regional Sveconorwegian amphibolite-facies, tectonometamorphic phase. These ages are constrained by $\mathrm{U}-\mathrm{Pb}$ ages from metasomatically generated rutile, titanite, and monazite between 1100 and $1070 \mathrm{Ma}$ in the Bamble area [50] and by a $\mathrm{U}-\mathrm{Pb}$ titanite age of $1080 \mathrm{Ma}$ in the Modum area [21]. A later event connected to Permian Oslo Rift activity is evidenced by Ar-Ar age dating of metasomatically produced $\mathrm{K}$-feldspar [88] and can possibly reflect the low-grade albitisation stage. Fluid infiltration during the Permian is indicated by alteration in the Bohus granite east of the Oslo Rift [89].

The progressive development of albitised schists and scapolite-bearing amphibolites described above illustrates the importance of metasomatic processes during crustal evolution. These mineral phases and lithologies have a widespread occurrence, extending outside the mapped albitites in Figure 1(b). Although not yet quantified, our results indicate the importance and extent of metasomatic influences on rock formation and structure on a regional scale.

\section{Conflicts of Interest}

The authors declare that they have no conflicts of interest.

\section{Acknowledgments}

This work is part of a regional geological mapping program in south Norway run by the Geological Survey of Norway (NGU) and supported by Fylkeskommunene TelemarkBuskerud-Vestfold.

\section{References}

[1] J.-M. Schmitt, "Geochemical modelling and origin of the Triassic albitized regolith in southern France, Recife, Brazil, abstract volume," in Proceedings of the in 14th international sedimentological congress, J. M. Mabesoone, Ed., vol. 14, pp. 1920, International Sedimentological Congress, Utrecht, Netherlands, 1994.

[2] K. Yao, M. Thiry, A. Szuszkiewicz, and K. Turniak, "Petrological characterization of the Triassic Paleosurface in the Northern Bohemian Massif," Geophysical Research Abstracts, vol. 12, pp. EGU2010-EGU7980, 2010.
[3] K. P. Helmold and P. C. van de Kamp, "Diagenetic mineralogy and controls on albitization and laumontite formation in Paleogene arkoses, Santa Ynez Mountains, California," AAPG Memoir, vol. 37, pp. 239-276, 1984.

[4] J. Coetzee and D. Twist, "Disseminated tin mineralization in the roof of the Bushveld Granite Pluton at the Zaaiplaats Mine, with implications for the genesis of magmatic hydrothermal tin systems," Economic Geology, vol. 84, no. 7, pp. 1817-1834, 1989.

[5] M. Rubenach, "Structural Controls of Metasomatism on a Regional Scale," in Metasomatism and the Chemical Transformation of Rocks, D. E. Harlov and H. Austrheim, Eds., Lecture Notes in Earth System Sciences, pp. 93-140, Springer Berlin Heidelberg, Berlin, Heidelberg, 2013.

[6] D. C. Ettner, A. Bjørlykke, and T. Andersen, "Fluid evolution and $\mathrm{AuCu}$ genesis along a shear zone: a regional fluid inclusion study of shear zone-hosted alteration and gold and copper mineralization in the Kautokeino greenstone belt, Finnmark, Norway," Journal of Geochemical Exploration, vol. 49, no. 3, pp. 233-267, 1993.

[7] E. S. Schandl, M. P. Gorton, and D. W. Davis, "Albitization at $1700 \pm 2 \mathrm{Ma}$ in the Sudbury-Wanapitei Lake area, Ontario: implications for deep-seated alkalic magmatism in the Southern Province," Canadian Journal of Earth Sciences, vol. 31, no. 3, pp. 597-607, 1994.

[8] F. H. Barthel, "Uranium occurrences in albitized rocks," Monograph Series on Mineral Deposits, vol. 27, pp. 1-9, 1987.

[9] C. M. Saunders and J. Tuach, "K-feldspathization, albitization and gold mineralization in granitoid rocks; the Rattling Brook alteration system western White Bay, Newfoundland," Current Research - Mineral Development Division (St. Johns), vol. 88, pp. 307-317, 1988.

[10] R. Frietsch, P. Tuisku, O. Martinsson, and J.-A. Perdahl, "Early Proterozoic $\mathrm{Cu}-(\mathrm{Au})$ and $\mathrm{Fe}$ ore deposits associated with regional $\mathrm{Na}-\mathrm{Cl}$ metasomatism in northern Fennoscandia," Ore Geology Reviews, vol. 12, no. 1, pp. 1-34, 1997.

[11] N. H. S. Oliver, J. S. Cleverley, G. Mark et al., "Modeling the role of sodic alteration in the genesis of iron oxide-coppergold deposits, Eastern Mount Isa Block, Australia," Economic Geology, vol. 99, no. 6, pp. 1145-1176, 2004.

[12] J. Touret, "Le facies granulite en norvege meridionale. I. Les associations minéralogiques," Lithos, vol. 4, no. 3, pp. 239-249, 1971.

[13] T.-L. Knudsen, "Petrology and geothermobarometry of granulite facies metapelites from the Hisøy-Torungen area, south Norway: New data on the Sveconorvegian P-T-t path of the Bamble sector," Journal of Metamorphic Geology, vol. 14, no. 3, pp. 267-287, 1996.

[14] J. Kihle, D. E. Harlov, Ø. Frigaard, and B. Jamtveit, "Epitaxial quartz inclusions in corundum from a sapphirine-garnet boudin, Bamble Sector, SE Norway: $\mathrm{SiO} 2-\mathrm{Al} 2 \mathrm{O} 3$ miscibility at high P-T dry granulite facies conditions," Journal of Metamorphic Geology, vol. 28, no. 7, pp. 769-784, 2010.

[15] I. A. Munz, "Whiteschists and orthoamphibole-cordierite rocks and the P-T-t path of the Modum Complex, south Norway," Lithos, vol. 24, no. 3, pp. 181-199, 1990.

[16] T. G. Nijland and C. Maijer, "The regional amphibolites to granulite facies transition at Arendal, Norway: Evidence for a thermal dome," Neues Jahrbuch für Mineralogie Abhandlungen, vol. 165, pp. 191-221, 1993.

[17] A. K. Engvik, B. Bingen, and A. Solli, "Localized occurrences of granulite: $\mathrm{P}-\mathrm{T}$ modeling, $\mathrm{U}-\mathrm{Pb}$ geochronology and distribution 
of early-Sveconorwegian high-grade metamorphism in Bamble, South Norway," Lithos, vol. 240-243, pp. 84-103, 2016.

[18] T. G. Nijland, D. E. Harlov, and T. Andersen, "The Bamble Sector, South Norway: A review," Geoscience Frontiers, vol. 5, no. 5, pp. 635-658, 2014.

[19] D. J. Lieftink, T. G. Nijland, and C. Maijer, "The behavior of rare-earth elements in high-temperature Cl-bearing aqueous fluids: results from the Odegardens Verk natural laboratory," The Canadian Mineralogist, vol. 32, no. 1, pp. 149-158, 1994.

[20] A. K. Engvik, K. Mezger, S. Wortelkamp et al., "Metasomatism of gabbro - mineral replacement and element mobilization during the Sveconorwegian metamorphic event," Journal of Metamorphic Geology, vol. 29, no. 4, pp. 399-423, 2011.

[21] I. A. Munz, D. Wayne, and H. Austrheim, "Retrograde fluid infiltration in the high-grade Modum Complex South Norway: evidence for age, source and REE mobility," Contributions to Mineralogy and Petrology, vol. 116, no. 1-2, pp. 32-46, 1994.

[22] J. A. W. Bugge, "Geological and petrographical investigations in the Kongberg-Bamble formation," Norges geologiske undersøkelse, vol. 160, p. 150, 1943.

[23] A. K. Engvik, P. M. Ihlen, and H. Austrheim, "Characterisation of Na-metasomatism in the Sveconorwegian Bamble Sector of South Norway," Geoscience Frontiers, vol. 5, no. 5, pp. 659-672, 2014.

[24] W. C. Brøgger and H. H. Reusch, "Norske apatittforekomster," Nyt Magazin for Naturvidenskaberne, vol. 25, pp. 257-300, 1880.

[25] T. Kjerulf and T. Dahll, "Om Jernertsernes Forekomst," Nyt Magazin for Naturvidenskaberne, vol. 11, pp. 294-359, 1861.

[26] J. H. L. Vogt, "Om dannelse af jernmalmforekomster," Norges geologiske undersøkelse, vol. 6, pp. 1-151, 1892.

[27] C. Kusebauch, T. John, J. D. Barnes, A. Klügel, and H. O. Austrheim, "Halogen element and stable chlorine isotope fractionation caused by fluid-rock interaction (Bamble sector, SE Norway)," Journal of Petrology, vol. 56, no. 2, pp. 299-324, 2015.

[28] D. E. Harlov, H.-J. Förster, and T. G. Nijland, "Fluid-induced nucleation of $(\mathrm{Y}+\mathrm{REE})$-phosphate minerals within apatite: nature and experiment. Part I. Chlorapatite," American Mineralogist, vol. 87, no. 2-3, pp. 245-261, 2002.

[29] A. K. Engvik, U. Golla-Schindler, J. Berndt, H. Austrheim, and A. Putnis, "Intragranular replacement of chlorapatite by hydroxy-fluor-apatite during metasomatism," Lithos, vol. 112, no. 3-4, pp. 236-246, 2009.

[30] C. Kusebauch, T. John, M. J. Whitehouse, and A. K. Engvik, "Apatite as probe for the halogen composition of metamorphic fluids (Bamble Sector, SE Norway)," Contributions to Mineralogy and Petrology, vol. 170, no. 4, article no. 34, 2015.

[31] H. Austrheim, C. V. Putnis, A. K. Engvik, and A. Putnis, "Zircon coronas around Fe-Ti oxides: A physical reference frame for metamorphic and metasomatic reactions," Contributions to Mineralogy and Petrology, vol. 156, no. 4, pp. 517-527, 2008.

[32] S. Dahlgren, R. Bogoch, M. Magaritz, and A. Michard, "Hydrothermal dolomite marbles associated with charnockitic magmatism in the Proterozoic Bamble Shear Belt, south Norway," Contributions to Mineralogy and Petrology, vol. 113, no. 3, pp. 394-409, 1993.

[33] R. Bast, E. E. Scherer, K. Mezger et al., "Boron isotopes in tourmaline as a tracer of metasomatic processes in the Bamble sector of Southern Norway," Contributions to Mineralogy and Petrology, vol. 168, no. 4, 2014.

[34] A. K. Engvik and H. Austrheim, "Formation of sapphirine and corundum in scapolitised and Mg-metasomatised gabbro," Terra Nova, vol. 22, no. 3, pp. 166-171, 2010.
[35] A. K. Engvik, A. Putnis, J. D. Fitz Gerald, and H. Austrheim, "Albitization of granitic rocks: The mechanism of replacement of oligoclase by albite," The Canadian Mineralogist, vol. 46, no. 6, pp. 1401-1415, 2008.

[36] D. L. Whitney and B. W. Evans, "Abbreviations for names of rock-forming minerals," American Mineralogist, vol. 95, no. 1, pp. 185-187, 2010.

[37] F. Pineau, M. Javoy, F. Behar, and J. Touret, "La geochimie isotopique du facies granulite du Bamble (Norvege) et l'origine des fluides carbones dans la croute profonde," Bulletin de Mineralogie, vol. 104, no. 5, pp. 630-641, 1981.

[38] P. Deines, "Stable Isotope Variations in Carbonatites," in Genesis And Evolution, K. Bell, Ed., pp. 301-359, Unwin Hyman, London, UK, 1989.

[39] M. Schidlowski, R. Eichmann, and C. E. Junge, "Precambrian sedimentary carbonates: carbon and oxygen isotope geochemistry and implications for the terrestrial oxygen budget," Precambrian Research, vol. 2, no. 1, pp. 1-69, 1975.

[40] M. A. Broekmans, T. G. Nijland, and J. B. Jansen, "Are stable isotopic trends in amphibolite to granulite facies transitions metamorphic or diagenetic? - an answer for the Arendal area (Bamble Sector, southeastern Norway) from mid-Proterozoic carbon-bearing rocks," American Journal of Science, vol. 294, no. 9, pp. 1135-1165, 1994.

[41] B. Bingen, W. J. Davis, M. A. Hamilton et al., "Geochronology of high-grade metamorphism in the Sveconorwegian belt, $\mathrm{S}$ Norway: U-Pb, Th- $\mathrm{Pb}$ and Re-Os data," Journal of Norwegian Geology, vol. 88, no. 1, pp. 13-42, 2008.

[42] S. V. Bogdanova, B. Bingen, R. Gorbatschev et al., "The East European Craton (Baltica) before and during the assembly of Rodinia," Precambrian Research, vol. 160, no. 1-2, pp. 23-45, 2008.

[43] P. Padget and H. Brekke, "Geologisk kart over Norge, berggrunnskart Arendal - 1:250 000," Norges geologiske undersøkelse, Trondheim, 1996.

[44] T. Andersen, W. L. Griffin, and N. J. Pearson, "Crustal evolution in the SW part of the baltic shield: The Hf isotope evidence," Journal of Petrology, vol. 43, no. 9, pp. 1725-1747, 2002.

[45] G.-J. L. M. de Haas, T. G. Nijland, T. Andersen, and F. Corfu, "New constraints on the timing of deposition and metamorphism in the Bamble sector, south Norway: Zircon and titanite U-Pb data from the Nelaug area," GFF, vol. 124, no. 2, pp. 73-78, 2002.

[46] T. Andersen, W. L. Griffin, S. E. Jackson, T.-L. Knudsen, and N. J. Pearson, "Mid-Proterozoic magmatic arc evolution at the southwest margin of the Baltic Shield," Lithos, vol. 73, no. 3-4, pp. 289-318, 2004.

[47] H. Baadsgaard, C. Chaplin, and W. L. Griffin, "Geochronology of the Gloserheia pegmatite, Froland, Southern Norway," Norsk Geologisk Tidsskrift, vol. 64, no. 2, pp. 111-10, 1984.

[48] T.-L. Knudsen, T. Andersen, M. J. Whitehouse, and J. Vestin, "Detrital zircon ages from southern Norway - implications for the Proterozoic evolution of the southwestern Baltic Shield," Contributions to Mineralogy and Petrology, vol. 130, no. 1, pp. 47-58, 1997.

[49] M. A. Cosca, K. Mezger, and E. J. Essene, "The BalticaLaurentia connection: Sveconorwegian (Grenvillian) metamorphism, cooling, and unroofing in the Bamble Sector, Norway," The Journal of Geology, vol. 106, no. 5, pp. 539-552, 1998.

[50] A. K. Engvik, F. Corfu, A. Solli, and H. Austrheim, "Sequence and timing of mineral replacement reactions during albitisation 
in the high-grade Bamble lithotectonic domain, S-Norway," Precambrian Research, vol. 291, pp. 1-16, 2017.

[51] R. C. Lamb, P. C. Smalley, and D. Field, "P-T conditions for the Arendal granulites, southern Norway: implications for the roles of P, T and CO2 in deep crustal LILE-depletion," Journal of Metamorphic Geology, vol. 4, no. 2, pp. 143-160, 1986.

[52] D. E. Harlov, "Pressure-temperature estimation in orthopyroxene-garnet bearing granulite facies rocks, Bamble Sector, Norway," Mineralogy and Petrology, vol. 69, no. 1-2, pp. 11-33, 2000.

[53] D. Visser and A. Senior, "Aluminous reaction textures in orthoamphibole-bearing rocks: the pressure-temperature evolution of the high-grade Proterozoic of the Bamble sector, south Norway," Journal of Metamorphic Geology, vol. 8, no. 2, pp. 231246, 1990.

[54] J. Touret and S. N. Olsen, "Fluid Inclusions in Migmatites," in Migmatites, J. R. Ashworth, Ed., pp. 265-288, Blackie, London, UK, 1985.

[55] T. G. Nijland and A. Senior, "Sveconorwegian granulite facies metamorphism of polyphase migmatites and basic dikes, south Norway," The Journal of Geology, vol. 99, no. 4, pp. 515-525, 1991.

[56] J. D. Brickwood and J. W. Craig, "Primary and re-equilibrated mineral assemblages from the Sveconorwegian mafic intrusions of the Kongsberg and Bamble areas, Norway," Norges Geologiske Undersøkelse Bulletin, vol. 410, pp. 1-23, 1987.

[57] W. C. Brøgger, "On several Archean rocks from the South Coast of Norway: II. The south Norwegian hyperites and their metamorphism," Det Norske Videnskaps-Akademi I Oslo, Skrifter, vol. 1, pp. 1-421, 1935.

[58] J. C. Green, "Geology of the Storkollen-Blankenberg area," Norsk Geologisk Tidsskrift, vol. 36, pp. 89-140, 1956.

[59] R. D. Morton, R. Batey, and K. R. O’Nions, “Geological investigations in the bamble sector of the Fennoscandian Shield of South Norway. I. the geology of eastern bamble," Norges geologiske undersøkelse, vol. 263, pp. 1-72, 1970.

[60] K. Govindaraju, "Compilation of working values and sample description for 383 geostandards," Geostandards and Geoanalytical Research, vol. 18, pp. 1-158, 1994.

[61] Z. D. Sharp, "A laser-based microanalytical method for the in situ determination of oxygen isotope ratios of silicates and oxides," Geochimica et Cosmochimica Acta, vol. 54, no. 5, pp. 1353-1357, 1990.

[62] D. Rumble III and T. C. Hoering, "Analysis of oxygen and sulfur isotope ratios in oxide and sulfide minerals by spot heating with a carbon dioxide laser in a fluorine atmosphere," Accounts of Chemical Research, vol. 27, no. 8, pp. 237-241, 1994.

[63] S. Kasemann, A. Meixner, A. Rocholl et al., "Boron and oxygen isotope composition of certified reference materials NIST SRM 610/612 and reference materials JB-2 and JR-2," Geostandards and Geoanalytical Research, vol. 25, no. 2-3, pp. 405-416, 2001.

[64] J. W. Valley, N. Kitchen, M. J. Kohn, C. R. Niendorf, and M. J. Spicuzza, "UWG-2, a garnet standard for oxygen isotope ratios: Strategies for high precision and accuracy with laser heating," Geochimica et Cosmochimica Acta, vol. 59, no. 24, pp. 5223-5231, 1995.

[65] T. W. Vennemann and J. R. O’Neil, “A simple and inexpensive method of hydrogen isotope and water analyses of minerals and rocks based on zinc reagent," Chemical Geology, vol. 103, no. 1-4, pp. 227-234, 1993.

[66] C. Spötl and T. W. Vennemann, "Continuous-flow isotope ratio mass spectrometric analysis of carbonate minerals," Rapid
Communications in Mass Spectrometry, vol. 17, no. 9, pp. 10041006, 2003.

[67] P. M. Valley, J. M. Hanchar, and M. J. Whitehouse, "New insights on the evolution of the Lyon Mountain Granite and associated Kiruna-type magnetite-apatite deposits, Adirondack Mountains, New York State," Geosphere, vol. 7, no. 2, pp. 357389, 2011.

[68] R. T. Gregory and R. E. Criss, "Isotopic Exchange in Open and Closed Systems," in Stable Isotopes in High Temperature Geological Processes, J. W. Valley, H. P. Taylor, and J. R. O’Neil, Eds., vol. 16, pp. 91-128, Reviews in Mineralogy, 1986.

[69] S. M. F. Sheppard, "Characterization and Isotopic Variations in Natural Waters," in Stable Isotopes in High Temperature Geological Processes, J. W. Valley, H. P. Taylor, and J. R. O’Neil, Eds., vol. 16, pp. 165-184, Reviews in Mineralogy, 1986.

[70] H. P. Taylor and S. M. F. Sheppard, "Igneous rocks: I. Processes of Isotopic Fractionation and Isotopic Systematic," in Stable Isotopes in High Temperature Geological Processes, J. W. Valley, H. P. Taylor, and J. R. O’Neil, Eds., vol. 16, pp. 91-128, Reviews in Mineralogy, 1986.

[71] G. Mark and D. R. W. Foster, "Magmatic-hydrothermal albiteactinolite-apatite-rich rocks from the Cloncurry district, NW Queensland, Australia," Lithos, vol. 51, no. 3, pp. 223-245, 2000.

[72] J. W. Valley, "Stable Isotope Geochemistry of Metamorphic Rocks," in Reviews in Mineralogy, J. W. Valley, H. P. Taylor, and J. R. O’Neil, Eds., vol. 16, pp. 445-490, 1986.

[73] N. H. S. Oliver, T. J. Rawling, I. Cartwright, and P. J. Pearson, "High-temperature fluid-rock interaction and scapolitization in an extension-related hydrothermal system, Mary Kathleen, Australia," Journal of Petrology, vol. 35, no. 6, pp. 1455-1491, 1994.

[74] D. P. Moecher, E. J. Essene, and J. W. Valley, "Stable isotopic and petrological constraints on scapolitization of the Whitestone meta-anorthosite, Grenville Province, Ontario," Journal of Metamorphic Geology, vol. 10, no. 6, pp. 745-762, 1992.

[75] A. Liebscher, "Experimental studies in model fluid systems," Reviews in Mineralogy and Geochemistry, vol. 65, pp. 15-47, 2007.

[76] T. S. Bowers and H. C. Helgeson, "Calculation of the thermodynamic and geochemical consequences of nonideal mixing in the system $\mathrm{H}_{2} \mathrm{O}-\mathrm{CO}_{2}-\mathrm{NaCl}$ on phase relations in geologic systems: Equation of state for $\mathrm{H}_{2} \mathrm{O}-\mathrm{CO}_{2}-\mathrm{NaCl}$ fluids at high pressures and temperatures," Geochimica et Cosmochimica Acta, vol. 47, no. 7, pp. 1247-1275, 1983.

[77] K. I. Shmulovich, S. I. Tkachenko, and N. V. Plyasunova, "Phase Equilibria in Fluid Systems at High Pressures and Temperatures," in Fluids in the Crust. Equilibrium and Transport Properties, K. I. Shmulovich, B. W. D. Yardley and, and G. G. Gonchar, Eds., pp. 193-214, Chapman \& Hall, London, UK, 1995.

[78] A. K. Engvik and B. Stöckhert, "The inclusion record of fluid evolution, crack healing and trapping from a heterogeneous system during rapid cooling of pegmatitic veins (Dronning Maud Land; Antarctica)," Geofluids, vol. 7, no. 2, pp. 171-185, 2007.

[79] A. Putnis, R. Hinrichs, C. V. Putnis, U. Golla-Schindler, and L. G. Collins, "Hematite in porous red-clouded feldspars: Evidence of large-scale crustal fluid-rock interaction," Lithos, vol. 95, no. 1-2, pp. 10-18, 2007.

[80] P. Padget, "Metasedimentary rocks, associated intrusions and tectonic features of the Precambrian in eastern Bamble, South Norway: an interpretative study," Norges geologiske undersøkelse Bulletin, vol. 442, pp. 39-51, 2004. 
[81] A. Weisheit, P. D. Bons, and M. A. Elburg, "Long-lived crustalscale fluid flow: The hydrothermal mega-breccia of Hidden Valley, Mt. Painter Inlier, South Australia," International Journal of Earth Sciences, vol. 102, no. 5, pp. 1219-1236, 2013.

[82] A. Weisheit, P. D. Bons, M. Danišík, and M. A. Elburg, "Crustal scale folding: palaeozoic deformation of the Mt painter inlier, South Australia," in Geological Society, London, Special Publications, vol. 394, pp. 53-77, 2014.

[83] D. T. Secor, "Role of fluid pressure in jointing," American Journal of Science, vol. 263, no. 8, pp. 633-646, 1965.

[84] H. R. Shaw, "The Fracture Mechanism of Magma Transport from The Mantle to The Surface Processes," in Physics of Magmatic, R. B. Hargraves, Ed., vol. 64, pp. 201-264, Princeton University Press, Princeton, 1980.

[85] T. J. Boone, P. A. Wawrzynek, and A. R. Ingraffea, "Simulation of the fracture process in rock with application to hydrofracturing," International Journal of Rock Mechanics and Mining Sciences, vol. 23, no. 3, pp. 255-265, 1986.

[86] T. M. Boundy, D. M. Fountain, and H. Austrheim, "Structural development and petrofabrics of eclogite facies shear zones, Bergen Arcs, western Norway: implications for deep crustal deformational processes," Journal of Metamorphic Geology, vol. 10, no. 2, pp. 127-146, 1992.

[87] A. K. Engvik, H. Austrheim, and T. B. Andersen, "Structural, mineralogical and petrophysical effects on deep crustal rocks of fluid-limited polymetamorphism, Western Gneiss Region, Norway," Journal of the Geological Society, vol. 157, no. 1, pp. 121134, 2000.

[88] M. R. Velo, Low-grade Prehnite-Pumpellyite facies metamorphism in the Bamble sector, SE-Norway [Master, thesis], Master Thesis, Department of Geosciences, University of Oslo, 2014.

[89] J. Petersson, A. E. Fallick, C. Broman, and T. Eliasson, "Imprints of multiple fluid regimes on episyenites in the Bohus granite, Sweden," Lithos, vol. 196-197, pp. 99-114, 2014. 

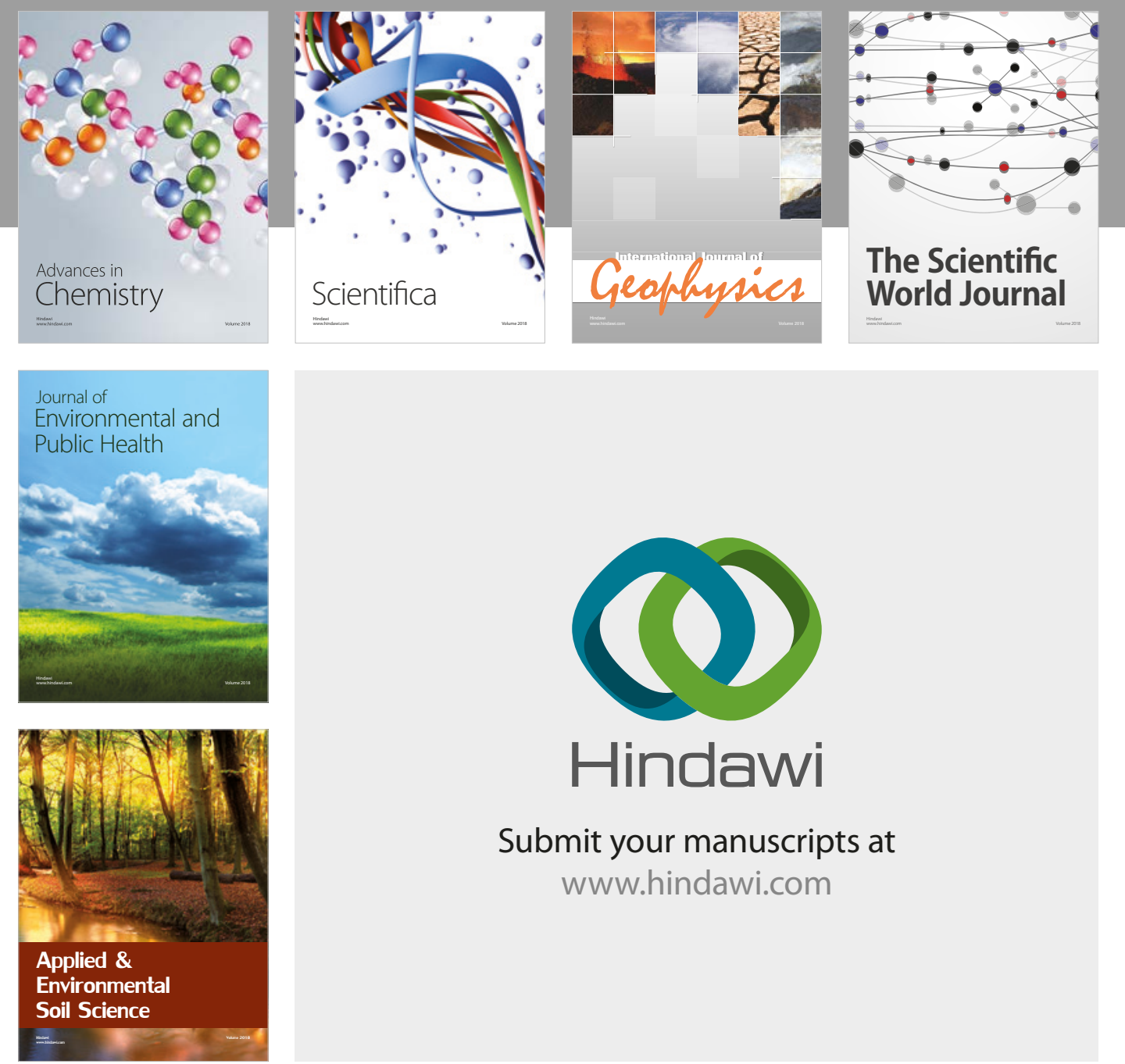

The Scientific

\section{World Journal}
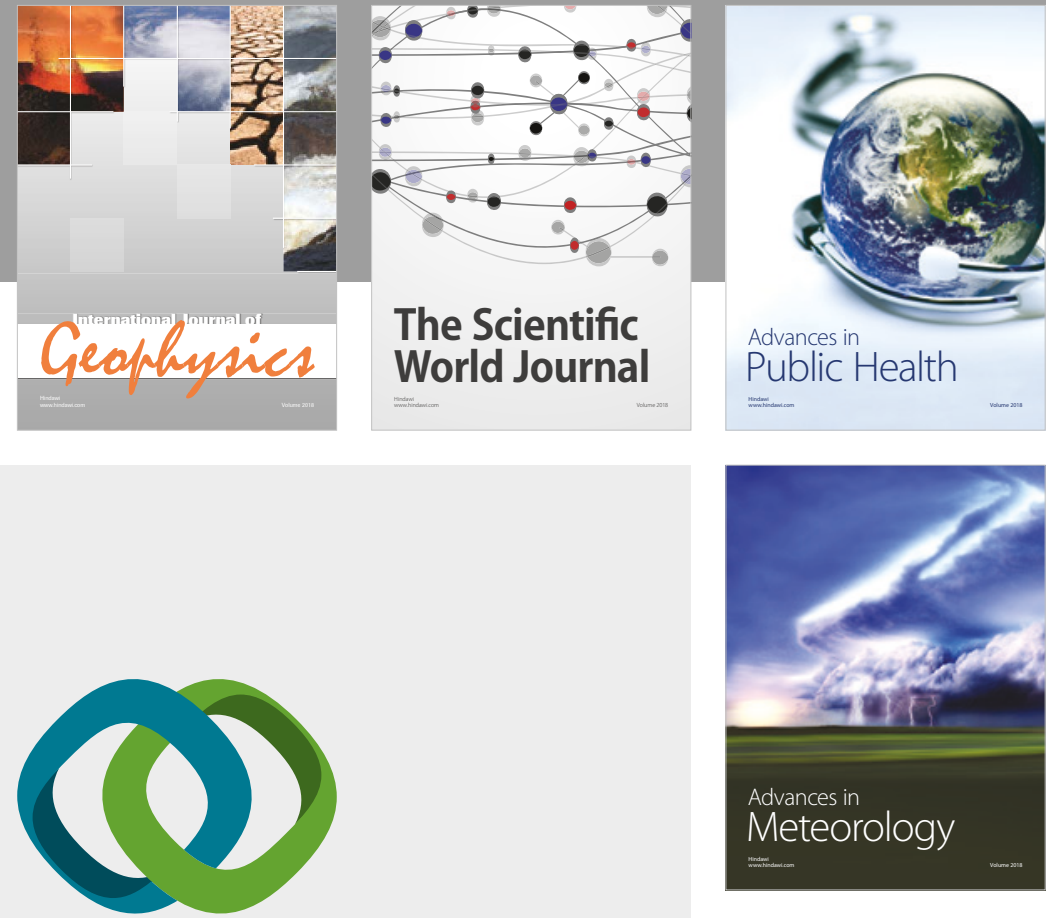

Advan

Public Health

\section{Hindawi}

Submit your manuscripts at

www.hindawi.com
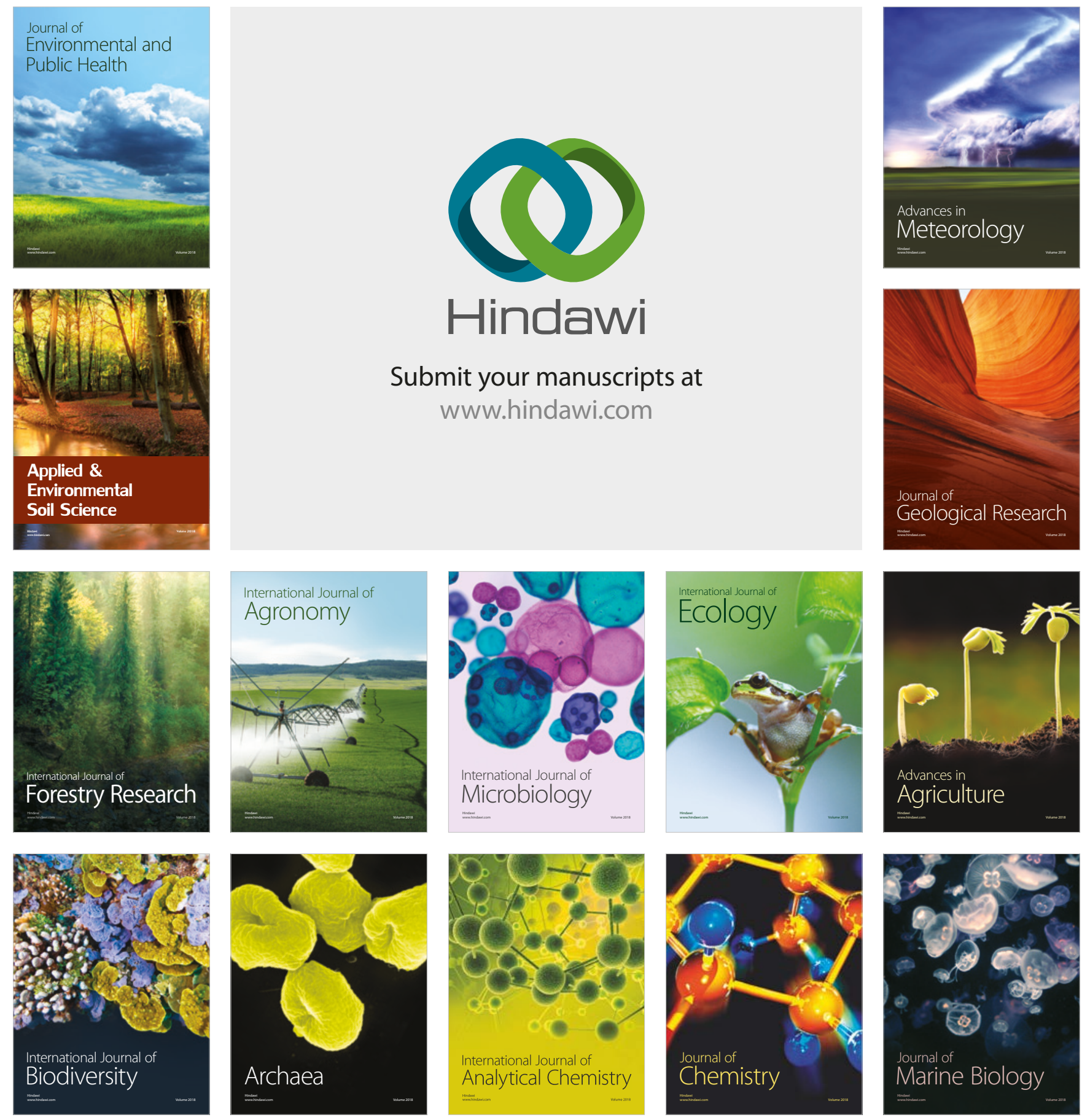